PART 4

Frontier Spaces 
$\Longrightarrow$ Taylor \& Francis

Taylor \& Francis Group

http://taylorandfrancis.com 


\title{
11
}

\section{HYPER-EXTRACTIVISM AND THE GLOBAL OIL ASSEMBLAGE}

\section{Visible and Invisible Networks in Frontier Spaces}

\author{
Michael John Watts ${ }^{1}$
}

\section{Introduction}

James Ferguson famously described African oil zones as "enclaved mineral-rich patches" where "security is provided....by specialized corporations while the... nominal holders of sovereignty...certify the industry's legality...in exchange for a piece of the action" (Ferguson, 2006, p. 204). His model of spatial mercantilism associated with "seeing like an oil company" has always struck me as out of sync with the political economic realities of both the world of oil in particular and extractive industries in general (see Ferguson, 2005). Seeing like an oil company privileges the notion that oil capital satiates its corporate appetite from its oil patches by barely touching down, alighting onto "patches" and operating through a logic of spatial confinement and enclosure. Ferguson radically confines the spaces of oil, as if all that mattered was the wellhead, the concession, or the international oil company's gated residential communities and corporate compounds. Rather, the oil well and the oilfield are planetary phenomena grounded in what Mezzadra and Neilson call the "operations of capital," an immense global assemblage of oil extraction, logistics, finance, and corporate power (Mezzadra and Neilson, 2019). The mine, the wellhead, the oilpatch - all must be deterritorialized or, to use different language, rendered planetary (Labban, 2014; Arboleda, 2020).

To take an African case, the enclaved oil-patch hardly captures the enormity of the hydrocarbon footprint across the oilfields of the Niger Delta, Nigeria, or indeed the larger oil cosmos of which it is part (Omeje, 2006; Adunbi, 2015). Virtually every inch of the region is touched by the industry, directly or indirectly. Over 6,000 wells have been sunk, roughly one well for every ten sq. km quadrant in the core oil-producing states. There are 606 oilfields (360 on shore) and 1,500 "host communities" with some sort of oil or gas facility or oil infrastructure. There are $4,315 \mathrm{~km}$ of multi-product pipelines and $7,000 \mathrm{~km}$ of crude oil pipelines, 
mostly owned and operated by a subsidiary of the national oil company, Nigerian National Petroleum Company (NNPC), 22 storage depots, 275 flow stations, ten gas plants, 14 export terminals, four terminal oil jetties, four refineries, and a massive LNG and gas supply complex. NNPC and its joint-venture partners (Shell, Exxon-Mobil, Total, and Eni), independents, and indigenous companies (such as Aiteo and Addax Petroleum) and a raft of related oil service companies directly employ an estimated 100,000 people - a figure that is certainly a considerable underestimate. It amounts to, minimally, a 65,000 sq km oil "patch." It bears repeating that what I have glossed over here is simply the logistical and infrastructural footprint of the industry.

The Niger Delta's oil frontier resembles an astonishing spatial patchwork, a quilt of multiple overlapping and intersecting spaces of territorial concessions, blocs, pipelines, risers, rigs, flowstations, and export terminals. Spatial technologies and representations are foundational to the oil industry: seismic devices map the contours of reservoirs, and geographic information systems monitor and meter the flows of products within pipelines. Hard rock geology is a science of the vertical, but when harnessed to the marketplace and profitability, it is the map that becomes the instrument of surveillance, control, and rule. The oil and gas industry are a cartographer's dream-space: a landscape of lines, axes, hubs, spokes, nodes, points, blocks, and flows. As a space of flows and connectivity, these spatial oil networks are unevenly visible (often subsurface and virtual) in their operations. A pipeline might run through a village alongside or even through residences and fields, only to disappear when it reaches a river or creek as engineers lay the pipelines into the river channel or into the sea; sometimes complex wellheads-Christmas trees is the professional term - might appear dramatically rising out of the water as if they were some terrifying sea-serpent. The delta is littered with plugged wellheads sitting in the middle of a cleared "pad" (often overgrown and heavily polluted), abandoned and typically oozing oil or hissing quietly (Amunwa, 2011; Amnesty International, 2015; Stakeholder Development Network, 2015).

Abandoned wells point to the larger trauma of serial oil spills dating back to the very origins of the industry in the late 1950s (Watts, 2008). The Nigerian Department of Petroleum Resources estimates that 1.89 million barrels of petroleum were spilled into the Niger Delta between 1976 and 1996 out of a total of 2.4 million barrels spilled in 4,835 incidents (see United Nations Development Programme, 2006). Data on pipeline malfunction (so-called "vandalizations" and "ruptures") provided by the NNPC for 2005-18 reveal a total of 35,670 incidents, and the volume of "petroleum products" lost over that period was 4,737,046 metric tons (33.7 million barrels) (Nigerian National Petroleum Company, 2008-2018). The recently established federal oil spill monitor agency (the National Oil Spill Detection and Response Agency, NOSDRA) identified a total of 12,628 spill events between 2006 and 2019. It is often said that the Niger Delta experiences the equivalent of an Exxon Valdez spill every year. ${ }^{2}$

As Gavin Bridge says, "the hole is the essential feature of the extractive landscape, but the hole is just the start" (Bridge, 2015; no page number). The actual 
footprint of the oil and gas system's enclave and its logistical and other infrastructures in the Niger Delta is just the beginning of a planetary story. Big oil (i.e. national and international oil companies and so-called indigenous operators) is part of a global value chain (Gereffi et al., 2005; Tsing, 2009). At its most capacious and expansive, this extractive assemblage includes a suite of commodity trading-houses, state actors, investment banks, engineering and service companies, shipping, refining, and logistics, including state and private security forces and other forms of surveillance. Critically, the assemblage also includes a heterogenous suite of other actors: oilfield insurgents, militias, local artisanal refiners, criminal organizations, trade unions, non-governmental organizations and advocacy organizations, both local and global (such as Global Witness and Amnesty International), multilateral development institutions, development assistance agencies, and transnational regulatory institutions such as the Extractive Industries Transparency Initiative (EITI) (Appel et al., 2015).

Is this assemblage best understood as an oil patch or perhaps as an enclave? I think neither. The idea of a vast and heterogeneous oil assemblage, replete with diverse actors and agents, exhibiting spatial complexity and the varied forms of territorialization, deterritorialization, and layered sovereignties that it entails, points to a rethinking of contemporary extraction in relation to global capitalism in its various neoliberalized forms. Such a rethinking is what the concept of hyper-extraction is designed to address. In spatial terms - that is to say with a full accounting of the layered and overlapping sovereignties associated with the production and management of a multiplicity of oil and gas spaces - what is on offer is something akin to what Henri Lefebvre calls spatial hyper-complexity: it is a territory (Lefebvre's term) of nested, overlapping, and fissioned spaces (Lefebvre, 2005). ${ }^{3}$ The enclave spaceperhaps less central than often thought-is but one element of an oil and gas world constantly in the throes of de- and re-territorialization. My chapter endeavors to shed some light on the oil assemblage and its spaces by focusing on the intersections of finance, logistics, and rent (and rentier relations) as forms of value extraction. Empirically, I draw from the Arctic, Nigeria, and Mexico and focus on two entry points into the operations of the assemblage, shedding light on the porous boundaries between the licit and illicit, formal and informal, the visible and the invisible (see also Appel, 2019): the first is oil theft, piracy, and artisan refining (as instances of what I shall call the invisible supply chain), and the second is the world of commoditytrading firms and so-called "first trades" (as an exemplar of the shadow world of global oil markets).

\section{What's Hyper About Hyper-Extractivism?}

Hyper-extraction can be construed in a number of related but distinctive ways. One is simply the expanded scale and output - the basic quanta-of resources extracted and consumed. From 1970 to 2017 the annual global extraction of materials ${ }^{4}$ grew from 27 billion tons to 92 billion tons, while the annual average material demand grew from seven tons to over twelve tons per capita, an annual 
average growth of 2.6 percent $^{5}$ (roughly twice the rate of population growth) (United Nations Environment Programme, 2019, p. 42). The new millennium ushered in a major increase in global material requirements, which grew at 2.3 percent per year from 1970 to 2000, but accelerated to 3.2 percent per year from 2000 to 2017, driven largely by major investments in infrastructure and increased material living standards in East Asia and the Pacific. While there was a brief slowdown in the growth rate of demand for materials between 2008 and 2010 as a result of the global financial crisis, this has clearly had a limited impact on the overall trajectory.

Over the last century, resource extraction from non-renewable stocks has grown while extraction from renewable stocks has declined as the agricultural economy has contracted in relation to manufacturing (Organization for Economic Co-operation and Development, 2015). Once accounting for some 75 percent of global material extraction, biomass today accounts for less than a third of total extraction. By 2010 non-renewable resource extraction represented over two-thirds of global material extraction, with construction minerals making up over 30 percent, fossil energy 20 percent, and metal and metal ores 13 percent. Fossil fuels - the most traded primary material accounting for half of the global total of 11.6 billion tons of direct physical exports currently-have grown in absolute terms from 6.2 billion tons to 15 billion tons, but their share in global extraction decreased from 23 percent in 1970 to sixteen percent in 2017. Natural gas, conversely, had a growth rate of 2.8 percent average yearly growth, and coal displayed 2.1 percent yearly growth, both in excess of petroleum with a 1.3 percent yearly growth. Global primary materials use is projected to almost double from 89 gigatons (Gt) in 2017 to 167 Gt in 2060 (Organization for Economic Co-operation and Development, 2018).

There are, naturally, other senses of hyper-extraction. One conjures up the speed, intensity, and energy (in the peculiar form of technological innovation) of contemporary extractive systems (Szeman, 2017). The rate and scale of extraction is one attribute of contemporary extraction's hyper qualities - the massive scars and land movement such as those entailed in the Canadian tar sands or Kennecott's Bingham Canyon copper mine-but there is relatedly the degree to which new technologies offer the possibility of enhanced recovery rates, the opening of new frontiers previously foreclosed (fracking is an obvious case), and the deployment of high-tech instruments for discovery, estimation, and surveillance of resources (three-D seismic imaging, for example, in deepwater mining). The very notion of the "digital mine," and the digital transformation of the oil industry, are cases in point (Mining Review Africa, 2019). An in-house industry journal puts it this way: "augmented reality, virtual reality, AI, intelligent automation, and the interconnectedness of all devices, hardware, and plant machinery will completely change the face of day-to-day oil and gas operations" (Oil and Gas IQ, 2019). The digital and the virtual point to the sector-specific interfaces between extraction and infrastructure, one expression of which is the ability to move, transform, and refine/process massive quantities of materials at unprecedented speeds for an array of novel end uses. Rare earths and their role in the informatics sector are simply one instance (Klinger, 2018). 
Hyper-extraction can also be put to service as a tagline for the capaciousnessthe planetary scope and scale-of the extractive supply-chain networks (Bridge, 2008). At stake is not simply the quanta of the commodity extracted but also the density, connectivity, and tensions among different but functionally related supply chains-extractive, manufacturing, finance, logistical-that intersect in extraordinarily complex global configurations resembling artist Mark Lombardi's global networks (Lombardi, 2003). In terms of logistical orders and global supply chains, oil and gas are arguably one of the vastest, complex, and securitized of infrastructural and logistical spaces (Cowen, 2010). In a way that other global supply chains are not, oil and gas have (since the early twentieth century) been a textbook illustration of a state-military-industrial-corporate complex. Like other infrastructures, oil and gas logistical systems are unevenly visible. They are both private and public (and sometimes hybrid mixes of both) and stand complexly in relation to spatial fixity: Pipelines might be fixed, but semi-submersible rigs are mobile between off-shore fields in between periods of sedentary drilling. It is often said that large-scale technical systems are a system of substrates, invisible until they malfunction; they are taken for granted and to that degree offer up an illusion of freedom. Filip de Boeck says: "[Infrastructures] are mainly present in their absence" (de Boeck, 2012). Deepwater rigs are cases in point: offshore and out of sight. Out of sight, that is, until they are not-as the massive Deepwater Horizon blowout in the Gulf of Mexico revealed. ${ }^{6}$ But the question of visibility is largely situational seen through the lens, say, of Americans filling up their gas tanks and in any case is only a partial truth. From another vantage point (on the oil patches or fracking fields), the logistical system is hyper-visible - pipelines running through villages, gas flares continuously emitting startlingly harsh illumination, wellheads on farmsteads, villages cheek by jowl with massive liquefied natural gas plants-the system is unavoidable and omnipresent (Larkin, 2013).

As a hyper-extractive assemblage, the oil and gas supply chain and its logistical orders operate less across a frictionless, smooth, monochromatic abstract space (in the sense deployed by Henri Lefebvre in The Production of Space) than through a networked mosaic of more or less regulated, more or less ordered, more or less calculable nodes, sites, and spaces. Take for example the oil "frontier." To the petro-geologist, the frontier is a geological province-a large area often of several thousand square kilometers with a common geological history-which becomes a petroleum province when a "working petroleum system" has been discovered. The play, or collection of oil prospects, has its own unique reservoir properties, temperatures, flow characteristics, viscosity, and so on. All mapped, calculated and ordered as part of a technological zone (Barry, 2006). But as part of the global supply chain, these plays are often at the margins and fringes, the so-called "liminal spaces" of the unregulated fracking fields of North Dakota or the Nigerian oil fields plagued by violence. All of this is characteristic of frontiers everywhere: namely, the parts of the extractive system marked by the circumvention of infrastructural and administrative grids of the formalized economy. Without these irregularities and asymmetries across the supply chain, there would, of course, be no 
arbitrage. After all, without this linking of, as it were, the ordered and disordered, the licit and illicit, the cores with the interstitial periphery, logistics with "counterlogistics" which constitute the circulatory politics and frictions of contemporary supply chain capitalism, it is not clear what all those financiers, speculators, hedge fund and equity managers would actually do.

Finally, and for this chapter most crucially, there is the meaning of hyperextraction as expanded, extended, or enhanced extraction. Extraction in this account has become "a generalized feature of capitalism as we know it today" (Ye et al., 2020, p. 171). It draws upon three related but slightly different strands of political economy. One is the move to deterritorialize and render "planetary" the mine, as explicated by Mazen Labban and Martin Arboleda, i.e. the idea that "capitalist urbanization secrets the planetary mine-everyday, above ground, scattered, diffuse, perpetual and swelling" (Labban, 2014, p. 564; see also Arboleda, 2020). Central to the planetary approach is not simply emphasizing scale, and interconnectivity (the city as the "inverted mine") and breaking with methodological nationalism. Rather, it is understanding extraction as a set of shifting dynamic frontiers produced and enmeshed in forms of contemporary racialized capitalism and empire. A second thread is the related work of Sandra Mezzadra and Brett Neilson in their book The Politics of Operations (Mezzadra et al., 2017; Mezzadra and Neilson, 2019) Their focus is on the production of multiple edges and frontiers of expanding capitalism, the layered sovereignties and variegated legal spaces of global capital, and the new spatial and temporal complexities of capitalism associated with capital's circulation and colonization of social life, or what they call the politics of operations. In particular, it is the operations of a trifecta of "sectors" and their connections that provide the core entry point: extraction, logistics, and finance. ${ }^{7}$

The final approach to the notion of an enlarged extraction requires a little more elaboration. I shall refer to it as extractive rents, a body of work that has collectively addressed the question of contemporary capitalism and "rule by rentiers" (Piketty, 2014; Standing, 2016; Mazzucato, 2018). Not surprisingly, financial rentiers, which is to say firms engaged primarily in financial activities and earning revenue primarily through the ownership and exploitation of financial assets, have been in the spotlight, the principal agents of what has come to be seen as the dominance of Wall Street and finance capital. As a form of critique, rents are seen as "unearned" (rather than productive as a source of accumulation). Owners of land, mineral resources, intellectual property, and a panoply of other income-generating financial and non-financial assets are seen to exercise a sort of hegemony within a neoliberalized and financialized capitalism. When economists refer to a rent-seeking political economy, they typically invoke a lack of market competition and see the source of rent as state intervention or restrictions on economic activity. Others see rent as any income derived from ownership, possession or control of assets (including financial assets) that are scarce or artificially rendered scarce. Implicit in differing explications of rent-all too complex to enter into here (see Christophers, 2019) - is the notion of both monopoly power not only of ownership or control but also in the marketplace. In this sense rent is income derived 
from the ownership, possession, or control of scarce assets under conditions of limited or no competition (2019).

Central to the rentier world is the determination and distribution of property rights that are not deployed to produce new commodities but rather to extract value via rent (what has been called "value" grabbing through "pseudo-commodities," see Andreucci et al., 2017). There is, to take the idea of a planetary extractive system, an expanding class of rentiers operating in the interstices of, for example, the multiple agents in the oil and gas assemblage (financiers, commodity traders, oil insurgents, politicians, military, corporations and so on) who profit without producing (Harvey, 2007; Lapavitsas, 2009). Rent-bearing assets-how they are created, their opportunities to extract value, and conflicts and struggles over the property rights that underlie them-are pivotal to contemporary capitalism, and to extraction in particular. The state figures centrally in rents for a trio of reasons: it customarily creates and institutes property rights, it typically regulates, enforces and legitimates the distribution of rights and titles and their use, and not least-and this is especially so in oil state where mineral rights are nationalized-it is itself a landlord or acts like a landlord (Hausmann, 1981; Schmitt, 2003). But these rights might also inhere in international law or through the operations of multilateral development institutions. Either way, "the proliferation of private property relations over everything imaginable significantly expands the terrain for rent extraction and related struggles" (Andreucci et al., 2017, p. 38). ${ }^{8}$

Rents (and the rentier state) have been a staple in the diet of extractive analysis for many decades (Mommer, 1990; Hertog, 2010) But planetary extraction, and the dominant forms of neoliberalized finance capital associated with it, point to the importance of the massive proliferation of rents and rent opportunities - "value grabbing"-within the operations of the oil and gas assemblage. This is no longer solely a product of corrupt rent-seeking petro-states but operates across multiple spaces and sectors, across the licit and illicit, and among cores and frontiers, a development which highlights the blurring of conventional borders in thinking about the global political economy of extraction (Ye et al., 2020). One of the purposes of this chapter is to elucidate the vast proliferation of rents in extractive economies understood at the planetary levels and show how these rents blur distinctions between legal and legal, formal and informal, state and civil society, boundaries, and frontiers.

\section{The Digital Arctic: Deepwater Oil as a Hyper-Extractive System}

A vignette. On August 2, 2007 a Russian submarine carrying two parliamentarians planted a titanium flag two miles beneath the North Pole. At stake were lucrative new oil and gas fields - by some estimations 10 billion tons of oil equivalent - on the Arctic sea floor. A decade later in December 2017, the U.S. National Oceanic and Atmospheric Administration (NOAA) - significantly, an arm of the U.S. Department of Commerce-released a report proclaiming a "New Arctic," signaling massive, irreversible changes in the material composition of the Arctic 
Ocean and its peripheries. ${ }^{9}$ A world of forbidding sea ice is now re-construed through the lens of runaway melt, thaw, liquefaction, and off-gassing and a new ocean emerges demanding to be observed, represented, documented, exploited, and policed at multiple scales. Confronting new systems of global oceanic and atmospheric circulation, a vast constellation of satellites, drones, buoys, cables, supercomputers, servers, and sensors will give form to the New Arctic, a "digital ocean" whose geo-economic and geostrategic value rests on forms of legibility and computational calculation. A liquid Arctic is both a knowledge and infrastructural frontier, calling into being new forms of "environmental intelligence" (EI) and logistical orders of extraction, circulation, and securitization. All of this is in the service of a new frontier of accumulation, a so-called "trillion-dollar ocean." What is at stake is building a logistics space for the Anthropocene. As Kalvin Henely (2012) put it: "if you think of Wall Street as capitalism's symbolic headquarters, ... the sea is capitalism's trading floor writ large."

One part of this digital Arctic story concerns resources, especially but not exclusively oil and gas. Deepwater oil and gas production in the Arctic (and elsewhere) is nothing new of course; the logistical and infrastructural investments in the oil and gas global supply chain have already left their profound footprints not simply on the ocean floor but in and through the oceanic world in the form of pipelines, flow-stations, risers, rigs, tankers, tank-farms, gas flaring vents, semi-submersible rigs, blowout preventers, and so on. ${ }^{10}$ It is now commonplace for test wells to delve through 7,000 feet and more of maritime waters and 30,000 feet of sea floor to tap oil in tertiary rock laid down 60 million years ago. A single test well might cost over $\$ 250$ million. A great deep-water land grab is under way: primitive accumulation at significant depths. Warming wrought by global climate change has opened Arctic prospects containing an estimated one-eighth of the world's remaining oil and a quarter of its gas (according to the U.S. Geological Survey). But the arrival of peak oil has triggered increasingly high-risk techniques and geographies of extraction, especially in deepwater and the extreme environments of the Arctic now amplified under conditions of climate change. ${ }^{11}$ NOAA has adopted Environmental Intelligence-rebranding itself as America's environmental intelligence agency-to mold the New Arctic policy narrative as a security concern through the problem of data production, management, and deployment. Adapted from long-standing military-scientific techniques of geographic, meteorological, and otherwise geophysical knowledge production, EI frames the New Arctic through an established military-industrial-academic complex operating at many levels-structural, logistical, and infrastructural.

What distinguishes the contemporary variant of EI, however, is the addition of speculative finance capital and its logics of risk (Arroyo, in progress). By changing the risk landscape, EI becomes a strategic domain of value that maps out possible scenarios and multiplies speculative opportunities by trafficking in New Arctic futures. Environmental Intelligence asserts the ascendancy of geospatial data in the valuation and evaluation of risky uncertain futures as a space of economic and political securitization - it is a sort of "emerging market." It makes use of the vast resources of Silicon Valley rather than the secret state technologies and military 
satellites, ships, and other sensing platforms typical of Cold War-era big science. Bay Area firms focus on small, automated, cheap systems-from Saildrone's unmanned solar and sail-equipped sensor packages to Planet Labs' CubeSat swarms - to produce data that is market ready for just-in-time maritime logistics, everywhere-war security operations, and for the extractive sector. The idea of a new Arctic Ocean endeavors to map a space of the yet-to-be observed, represented, exploited, and policed, at multiple spatial and temporal scales (see Mason, in press), as an epistemic object and a logistical order in the m making, expanding the means by which the region's strategic worth is evaluated. NOAA's coinage of the New Arctic might appear to be a predominantly American techno-political project. But it is a supranational enterprise as important to Norway or Russia as it is to China or Canada.

But data collection is the leading edge of finance capital and state-led investment. As NOAA was rebranding itself, Guggenheim Investment Partners LLC, a New York firm, offered the first Arctic-specific investment portfolio, while China published a comprehensive Arctic strategy for a Polar Silk Road. The U.S. Defense Advanced Research Project Agency seeks to deploy sensor networks of floatation devices for real-time maritime monitoring in an Ocean of Things, while U.S. defense contractor and ocean technology startup Liquid Robotics, a Boeing subsidiary, has outlined its vision for a digital ocean. The Arctic mineral and energy frontier are thus what Alexander Arroyo calls a "geography of speculation" (Arroyo, 2020).

Oceanic oil and the digital Arctic reveal how the concept of hyper-extraction offers a sort of full-screen technicolor picture of the twenty-first century extractive political economy. It points to a planetary oil and gas assemblage in which the politics of operations on the ground encompass extraction, logistics, technology, and finance. In rendering the wellhead "planetary," it offers an important reckoning: extraction is less an old-world nineteenth century industry rooted in classical imperialism than a leading edge of contemporary capitalism ceaselessly searching for new frontiers of real and formal subsumption of nature (Murray, 2004; Boyd et al., 2001).

\section{The Planetary Well: Oil Theft and Illicit Capitalism}

On April 18-19,, 2018, a global conference, Oil and Fuel Theft 2018, was held in Geneva. Building upon the work of the Atlantic Council, the conference aimed to forge a global network of stakeholders in order to share information, expertise, and other mutual support in taking on "a worldwide threat to security and prosperity." Oil and Fuel Theft 2018 drew 140 attendees from around the world, including the leadership of national oil companies (NOCs) from Iraq, Libya, Mexico, Ghana, and Uganda, as well as government delegations from the USA and the Philippines and multilateral organizations such as the World Customs Organization and the International Maritime Organization, international oil and service companies, and other corporate actors such as Dow Chemical. Among the offerings was striking testimony by General Mahmound al-Bayati, Director-General Counter-Terrorism and National Security Advisor for the Republic of Iraq, who outlined the history and 
genesis of how large-scale oil and fuel smuggling took root and in his countrycoming to light in the infamous corrupt Oil-for-Food Program between 1995 and 2003-including the dynamics of oil smuggling for profit by Islamic State in Iraq and Syria (Vienneast, 2016; Tichý, 2019). But the Islamic State and its oil investments are simply the tip of an iceberg, and these patterns are repeated the world over.

The Atlantic Council's three recent reports-Downstream Oil Theft: Global Modalities, Trends, and Remedies; Downstream Oil Theft: Implications and Next Steps; and Oil on the Water: Illicit Hydrocarbons Activity in the Maritime Domain-offered the first comprehensive picture of global hydrocarbon crime. The scale of the illicit oil economy is mind-boggling. Globally, it is estimated that $\$ 133$ billion worth of oil and fuel annually is stolen, adulterated, or fraudulently transferred at some point in its supply chain, an estimate that includes only refined (and not crude oil) products. But this figure is a massive underestimate, as it does not include the sorts of losses associated with fraudulent oil trading contracts or oil revenues unaccounted for or "lost" through public financial institutions in oilstates like Venezuela or Nigeria. Liquefied gas is also stolen and illicitly traded. Crucially, oil theft is not simply the preserve of petro-states in the Global South marked by "poor governance." In the European Union, revenue loss caused by theft of oil and fuel is estimated to be worth $€ 4$ billion; the illicit cross-border trade in oil between Mexico and the United States involving not just Mexican cartels but American trading houses and oil companies is a multi-billion dollar business network (Reinhart, 2014; Jones and Sullivan, 2019). This illicit money machine not only turns on organized criminal gangs, terrorist groups, and insurgents but on corrupt public officials and security forces, offshore financial centers, and the global oil leviathan. What is on offer is a sort of global oil mafia operating in the interstices of the oil and gas global value chain.

Oil theft points to a larger systemic and structural pathology within the vast oil and gas complex-according to market research by IBISWorld the total revenues for the oil and gas drilling sector came to approximately $\$ 3.3$ trillion in 2019 , roughly four percent of global $\mathrm{GDP}^{12-}$ namely, endemic corruption and illicit financial flows (Organisation for Economic Co-operation and Development, 2016). In resource-rich post-colonial states, somewhere between 25 percent and 55 percent of global capital flows could be illicit. It is widely acknowledged that illicit finance capital is deeply enmeshed with international crime networks (narcotics, arms, smuggling) and illicit commercial practices like tax and pricing fraud. Twenty percent of the 242 enforcement actions under the U.S. Foreign Corruption Practices Act came from the extractives sector-by far the highest for any industry, while of the 427 foreign bribery actions examined in a 2014 Organisation for Economic Co-operation and Development (OECD) report, twenty percent were lodged in the extractive sector (Organisation for Economic Co-operation and Development, 2014; Foreign Corrupt Practices Act Clearing House, 2018).

The scale of illicit financial flows (IFF) in extractive economies across the Global South is gargantuan. According to Global Financial Integrity, the real normalized 
cumulative IFFs from Sub-Saharan Africa (SSA) between 1980 and 2009 amounted to $\$ 846$ billion (over $\$ 40$ billion per year in the 2000s) (Global Financial Integrity, 2013); UNECA, 2018). Net recorded outflows from West and Central Africaand from the trio of oil producers, Nigeria, Congo, and Angola-swamped recorded transfers into other regions over the decade ending 2009. Oil and gas exports accounted for over 55 percent of all IFFs in SSA during the same period. Data from the Brookings Institution estimate that between 1980 and 2018 SSA received nearly $\$ 2$ trillion in foreign direct investment and official development assistance, but produced over $\$ 1$ trillion in illicit financial flows: four of the top seven IFF African producers of illicit flows 1980-2018 (totaling almost \$200 billion) are oil producers ${ }^{13}$ (Signé et al., 2020).

Oil and gas provide the richest of soils for IFF risk. State control of the industry in producer states is widespread and provides a massive hunting ground for rents on the part of the political, military, and business classes. The global supply chain is deeply financialized, not only in the investment required for exploration and production but also and especially in the trading system, a domain marked by opacity. OECD's typology of corruption risks across the extractive sector analyzed 131 corruption cases, including oil and gas, and noted that corruption risks might arise at any point in the extractive value chain (Organisation for Economic Co-operation and Development, 2016). The award of mineral, oil, and gas rights, and the regulation and management of operations accounted for almost 75 percent of all cases, and involved bribery of foreign officials, embezzlement, misappropriation, and diversion of public funds, abuse of office, trading in influence, favouritism, and extortion, bribery of domestic officials and facilitation payments. Large-scale, socalled "grand," corruption involving high-level public officials is widely associated with the award of mineral and oil and gas rights, procurement of goods and services, commodity trading, revenue management through natural resource funds, and public spending. Sophisticated vehicles for channeling illegal payments, disguised through a series of offshore transactions and complex layers of corporate structures often involving shell companies, are recurrent features of the oil and gas sector landscape.

Perhaps no country on earth is more closely associated with large scale oil theft ("bunkering") than Nigeria (though Mexico, Iraq, and Russia follow close behind). ${ }^{14}$ The scale and costs of hydrocarbon crime in Nigeria are notoriously difficult to quantify because of the multiplicity of points where oil in its various expressions (crude, kerosene, refined petroleum, oil revenues) is stolen, but also because Nigerian state and regulatory authorities, as well as corporate actors, lack consistent and accurate metrics. In fact, the commonly expected global standards for measuring and metering across the national supply chain are weak or absent. Estimates of crude oil and fuel stolen and revenues lost vary, often widely, as indeed does the data on pipeline sabotage and attacks. Nigeria lost approximately 204 million barrels, valued at 4.57 trillion naira (roughly $\$ 18$ billion), to oil theft in the four years between 2015 and 2019, according to estimates by the Nigeria Natural Resource Charter (NNRC); that is to say, the Federal Government lost 
approximately 43 percent of its revenue to oil theft over four years (Nigeria Natural Resource Charter, 2018; Nasir, 2020; Nigeria Business News, 2020). Nigerian EITI estimated oil theft at $\$ 42$ billion between 2009 and 2018 (Nigeria Bulletin, 2020). According to international oil company figures, Chevron, Shell, and Nigerian Agip Oil Company lost \$11 billion between 2009 and 2011 owing to theft and sabotage. The NNPC, which is the parastatal charged with management of the industry, spent $\$ 2.3$ billion on pipeline repairs and security from 2010 to 2012 and almost $\$ 100,000$ million in the first quarter of 2019 alone. By some estimates, 500,000 people are employed in the theft business, broadly defined. ${ }^{15}$

Illegal bunkering of Nigerian crude oil originated in the 1960s in part during the Biafran civil war (1967-70) but subsequently expanded under military rule when top army and navy officers began stealing oil-or allowing others to steal it - to enrich themselves and maintain political stability while also busting tight OPEC quotas. Local and foreign intermediaries did much of the legwork-Lebanese and Greek enablers loomed large-but the scale was small, perhaps a few thousand barrels per day. According to some reports (Katsouris and Sayne, 2013), lower global oil prices and Nigerian output, combined with the relatively closed group of actors involved, helped contain the business. Growing involvement by the Nigerian security forces after military rule ended in 1999 and active involvement by Nigerian political and business classes (so-called political "Godfathers," well-placed political party members and high-ranking civil servants) all pointed to the rise of a wellorganized "oil mafia." As militancy arose across the oilfields in the 2000s a new set of actors-insurgents, armed criminal and youth groups, local chiefs and political operatives - muscled their way into the oil theft business. All of this pointed to an oil black market of a systemic sort: the illicit capture of various assets and rents in the oil system, shady oil contracts and licenses, opaque "oil swaps," fraudulent trading deals, and the pillaging of public revenues (derived from oil) that course through the country's fiscal federal system (Watts, 2015; 2018).

\section{Pipelines, Taps, and Topping up: The Illicit Life of a Barrel of Oil}

Let's start with a wellhead in the Niger Delta, Nigeria. Nembe Creek Well 7, behind Mile 1 Community in Bayelsa State, feeds into the $97 \mathrm{~km}$ pipeline, Nembe Creek Trunk Line (NCTL). The trunk line is one of Nigeria's major oil transportation arteries that evacuates crude from the onshore fields to the Atlantic coast for export. Owned by Aiteo Group, NCTL was recently purchased from Shell Petroleum Development Company (SPDC) as part of the related facilities of the prolific oil block OML 29. NCTL's construction commenced in 2006 and was finally commissioned in 2010 at the cost of $\$ 1.1$ billion. Billed as a replacement to the ageing and often vandalized Nembe Creek Pipeline which had suffered significant losses due to incessant fires, sabotage, and theft, SPDC made use of the pipeline to transport crude oil from the OML 29 starting at Nembe Creek to a manifold at the Cawthorne Channel field on OML 18, and finally to the Bonny Island oil terminal for export (and for liquefied natural gas). In December 2011, 
barely one year after the line was commissioned, the pipeline was shut down for one month to repair leaks caused by crude thieves. In early 2012 Shell claimed that crude oil valued at $\$ 16$ million (over 60,000 barrels per day) was being stolen daily from the NCTL (Clark, 2014). Two short sections of pipelines in Brass and Nembe local government areas had over 600 attacks (theft, sabotage, operational failures) between 2006 and 2019, and over 200 oil theft events in a two-year period (2012-14) (Whanda et al., 2017; Ngada, 2018). Within a year of opening, Shell discovered 17 bunkering (theft) spots along $3.8 \mathrm{~km}$ of the pipeline (Ogunde, 2012). The NCTL pipeline is arguably one of the most attacked, sabotaged and compromised pipelines on the face of the earth. ${ }^{16}$ Typically- that is to say when it is not shut in by force majeure - the pipeline seems to be losing more oil than it is transporting.

In national terms, the collective assault on the integrity of Nigeria's pipelines is staggering: according to government data (the accuracy of which is open to question), in the oil producing Niger Delta alone between 2006 and 2019 there were over 12,000 spill events, 75 percent of which were located in three states, Bayelsa, Rivers, and Delta, and over 35,000 pipeline "incidents" (National Oil Spill Detection and Response Agency, 2020; Nigerian National Petroleum Company, 2020). Officially, the government record says that over three-quarters of all spills and incidents were due to "sabotage," which includes acts of oil theft and attacks on infrastructures by anti-state militant groups. Pipeline ruptures and oil theft in particular have waxed and waned over time; since the return to civilian rule in 1999 the incidence, regularity, and quantity of oil theft has fluctuated shaped in part by the electoral cycle, by the price of oil, and by shifting patterns of criminal and militia activity. Theft reached the staggering height of around 350,000 barrels per day and between 2006 and 2009, when an armed insurgency threw the oil fields into disarray and oil theft was funding the rebel cause (see Watts, 2007; Obi and Rustad, 2011; Nwajiaku-Dahou, 2012; Adunbi, 2015). However, since the signing of the government amnesty with 30,000 militants in 2009, oil theft has only increased (Rexer, 2019).

\section{The Ontological World of the Illegal Tap}

Let's now follow that barrel of crude ${ }^{17}$ as it passes from the wellhead into the trunk pipeline (the story might be slightly different if the pipeline is carrying refined fuels or gas). Within a short distance of the well, the crude flow is compromised by a "hot" or "cold tap," either on land or, if the pipeline is running along the floor of the creeks and estuaries of the delta, underwater. Hot tapping involves creating a branch connection to a pipeline in which the oil is flowing under pressure. To access lines running underwater and to conceal the tap, a small area of swamp around the pipe might be cordoned and drained and an isolating valve is welded or fitted mechanically to the pipe. After fitting - and with the valve open - the pipe is drilled to the maximum size through the valve, or the pipe is drilled part-way through and doused with sulfuric acid to complete the job once the line is in place. 
Exceptional skill and knowledge is required of oil infrastructure-the sparks from drilling easily ignite the fuel-and tapping is typically undertaken by corrupt or former oil-industry technicians and engineers, or increasingly by a class of professional "bunkerers" who are part of "unions" or small corporate groups. In more elaborate (and large scale) bunkering, crude oil might be diverted from manifolds or flow stations ${ }^{18}$ rather than individual pipelines, operations that require complicity and corrupt behavior from both local security forces and company operators.

In cold tapping, criminal or armed militias (sometimes referred to as oil gangs or oil mafia) blow up a pipeline, putting it out of use long enough for them to attach a spur pipeline. Many but not all pipeline bomb attacks appear to be linked to oil theft in order to enable a spur pipeline to be fitted, but during the period of armed insurgency in the Niger Delta (2005-2006, and earlier periods of activity by armed militias (2003-04, for example), attacks were launched in retaliation for military operations or as a way of extorting payments from transnational oil companies anxious to avoid force majeure (these were typically cash payments disguised as community development made to community "youth organizations"). The illegal spur pipeline transports the crude, often over several kilometers, to a convenient creek, where it is released into flat bottomed loaders (barges) or wooden "Cotonou boats" and then transshipped to differing locations, local, regional, and international.

All stolen oil that is taken out of Nigeria for sale elsewhere-probably about 80 percent of all stolen oil until recently - appears to be initially transported in surface tanks or barges. Much of the oil to be distributed within Nigeria-depending upon the quantity either to local refiners or to major state-run refineries—appears to be transferred into drums, generally transported by trucks, or after local refining by canoe to remote creek communities. The ability to tap with impunity requires the complicity of and the payment of rents by the tappers to local military and security forces (the Joint Task Force), local police, coastguards, security, and low-level technical operators working for oil companies, local militants (they can be so-called secret societies, vigilante groups, ethnic militias or anti-state insurgents such as the Movement for the Emancipation of the Niger Delta (MEND) who "tax" the movement of stolen crude near their creek encampments, and village chiefs and other youth groups in oil "host communities."

Arranged in and around the tap and its installation, in short, is an ensemble of actors and agents held together by patterns of value extraction and rent, at once a sort of ontology of infrastructures and a political order of invisible supply chains (see Ostensen and Stridsman, 2017). The local tappers (skilled welders with experience in the industry as opposed to those hacksaw or puncture siphons) typically work in teams of 3-6 people. Their proliferation, particularly post-2009, and their networked relations with security forces and actors within the industry (the oil company community liaison officers, flowstation technicians, oil service companies) has resulted in the rise of informal "unions" (Stakeholder Democracy Network, 2017; 2018). These unions can arrange for a tap placement (a recent report says the fee is roughly $\$ 6,200$ - in a country where per capita income is $\$ 2,300$ ) arranging often for the reduction in pressure on the pipelines by having 
company officials in the control rooms in the flow stations on their payroll. The unions provide security by paying off local security forces and "settle" with local community leaders.

Operating the tapping points, irrespective of the scale of the tap, entails a "consortium" of security (by local youth and payoff to local state and federal security forces), technical capability and operational access capable of earning around $\$ 1$ million a month; the monthly costs entail a union fee $(\$ 500)$, security payoffs $(\$ 1,200)$ and labor and equipment $(\$ 4,500)$. Payments to local community leaders in the oil host communities and to company technicians constitute additional expenditures. The union, provided with protection by local armed youth groups, delivers the oil to barges that either move offshore or arrange for local delivery to artisanal refiners. All along this local tapping and transporting supply chain are points of value extraction through rents which might take the form of extortion as much as formalized bribes.

All of the oil companies, including the national oil company, in theory provide surveillance and security to manage pipelines for reasons of safety and security. The costs of spills and explosion in and around communities, farms and fishing grounds are especially high. Yet the massive proliferation of what the companies and government agencies see as sabotage and theft suggests that either these systems are weakly enforced, or there is widespread collusion. Along some of the major trunk lines there are serial taps-in some sections there could be literally 100 or more taps per year (Ngada and Bowers, 2018). Both the companies and the federal government, moreover, have made use of local unemployed youth (as an employment strategy for a massive wageless class of alienated and frustrated youth across the region) to protect pipelines. But this in turn, building upon long standing grievances between communities and the companies, has simply provided yet more avenues for value extraction and rent-seeking.

Since 2009, as part of the Amnesty Plan, the federal government essentially has placed some 30,000 amnestied militants and their commanders on their payroll. This demobilization strategy provided security contracts ("surveillance contracts") to the most powerful commanders - and to oil host community chiefs and local contractors - to protect infrastructure. Not surprisingly, the amnesty program created tensions and conflict between former militias and their leaders squabbling over payments, while in practice superintending over the criminal oil theft enterprise. These surveillance functionaries were in effect "ghost workers" rarely carrying out any work while the amnesty program provided expanded opportunities to extract rents while converting commanders into local "businessmen" and indirectly funding private armies. ${ }^{19}$

Oil theft's world of rents, "taxes," and extortion is not confined to the world of tapping, shipping, and security, but also extends to environmental clean-up and restoration. In view of the overwhelming number of spills and pipeline interdictions each year, both corporations and federal and state regulatory agencies are liable for remediation. A number of federal and state agencies have jurisdiction over the oil and gas spillage response system, but for regulatory purposes it is the 
Joint Investigation Process (JIV) - which entails the submission of four forms to the national regulatory agency (NOSDRA) and a similar JIV independent assessment by the company - that offers inordinate space for graft (Amnesty International, 2015; 2018). The framework under which such assessments are conducted-contained in the Oil Spill Recovery, Clean-up, Remediation and Damage Assessment Regulations, of 2011 ("Clean-up")—requires that a joint investigation team (JIT), comprising of the owner or operator of the facility from which oil has spilled, community and state government representatives, and NOSDRA, be constituted immediately after an oil spill notification is made, which ordinarily should be within 24 hours of the occurrence. The JIT is required to visit the spill site and investigate the cause and extent of the spillage and under regulation 40 of the Clean-up regulations, it entails a physical evaluation of the soil and surrounding environment in order to determine the impact of the incident, proper remediation procedures, and monitoring the remediation progress.

The horizons for value extraction when oil companies, the state and impoverished poor communities are brought together in a "stakeholder process" are legion. Amnesty International noted that " $[\mathrm{t}]$ he process is heavily dependent on the oil companies: they decide when the investigation will take place; they usually provide transport to the site of the spill; and they provide technical expertise, which the regulatory bodies lack" (Amnesty International, 2013, p. 14). Participatory involvement is relatively limited and tokenistic: few members of the community are able to participate; typically, the oil companies deal with chiefs - or those they designateand male youth leaders. Not infrequently, community representatives are asked to sign incomplete forms and communities denied a copy of the form after signing it. Individuals are frequently paid to sign a JIV and company contractors in turn pay to get the clean-up contract. For example, a spill in Bayelsa State at Ikarama in 2011 at a Shell facility illustrates intersecting forces of lack of transparency, of an inadequate response system capable of effectively responding to conditions in the Delta, and the corruption of the JIV process itself (Olawuyi and Tubodenyefa, 2018). Pressures and payoffs exerted by the operators including threats by security agencies resulted in the coercion of the community stakeholders to acquiesce and agree to the finding of sabotage even though the communities believed it was operational failure.

When viewed through the prism of regulation and surveillance, the oil theft, the spill and clean-up system is one in which an array of foxes (regulators, companies, military, chiefs, militant commanders) are deployed to guard the henhouse. The assemblage is a shadow world of bribes, intimidation, extortion, fraud and illicit finance. The federal military forces provide protection for the major actors while offering a veneer of state legitimacy (taking the problem of oil theft seriously) by arresting, without necessarily prosecuting, low level barge operates and large numbers of small artisanal refineries, all the while leaving the black market operations intact. As amnesty payments dried up, or were absconded with by the commanders, and as employment opportunities through government programs declined as oil prices collapsed in 2014, many of the former militants had incentives to turn to artisanal refining and expanded tapping of pipelines. 


\section{Topping Up and the Piratical World}

Tapping-hot or cold - is only one among a number of means to steal crude oil. There are others. One is "topping up" at the export terminal. Oil company employees can be bribed into allowing unauthorized vessels to load. Authorized vessels can be topped - filled with oil beyond their stated capacity — and the excess load sold. Oil revenues can also be embezzled, or money made through the sale of export licenses, credentials, bills of lading, and so on. This "white collar" branch of oil theft allegedly involves pumping illegally obtained oil onto tankers already loading at export terminals, or siphoning crude from terminal storage tanks onto trucks. Bills of lading and other shipping and corporate documents might be falsified to paper over the theft. Some topping off might also happen at sea via ship-to-ship transfer when barges holding up to 3,000 metric tons of oil unload onto smaller tankers with a capacity of 10,000 metric tons anchored offshore. Thieves generally use these small tankers to store and transport oil locally, although a few of the more seaworthy vessels might carry stolen oil to refineries or storage tanks within the Gulf of Guinea. Several small tankers can service a single oil theft network. Once the crude stored in them builds to a certain level, crews transfer it to a coastal tanker or an international class "mother ship" waiting further offshore. These ship-to-ship (STS) operations, typically occurring at night, can involve topping up a legal cargo of oil or filling an entire mother ship.

Oil theft from export terminals entails a different set of actors from within the upper echelons of the industry as well as a set of international agents - the shipping companies and a network of commodity traders and financiers - who can arrange for the international transfer and sale of oil products in China, North Korea, Israel, and South Africa. Political actors have a key role "due to their formal role in Nigeria's economy, as government regulators of the oil and maritime industries in Nigeria, or as businesspeople who process oil, provide support services to oil firms, and ship oil" (Hastings and Phillips, 2015, p. 457). They are enablers and intermediaries standing between local economic and political networks and international actors operating in the global oil assemblage.

The other means of stealing crude oil is piracy, which entails both different actors, different networks and different forms of rent extraction (Balogun, 2018). The Gulf of Guinea, on West Africa's southern coast, and Nigeria's coastal waters in particular, has become the world's most pirate-infested sea (Lopez-Lucia, 2015; Jacobsen and Nordby, 2015). The International Maritime Bureau reports that attacks on vessels at sea between Ivory Coast and Cameroon have grown dramatically since the early 2000s. Piracy has been common in Nigerian coastal waters over the last two decades with the region's booming oil theft and kidnappingransom economy, while in other piracy hotspots (Somalia, southeast Asia) piracy is in decline (The Economist, 2019). Niger Delta-based piracy has a historically long pedigree dating to the nineteenth century, but since the amnesty of 2009 pirates have the wind in their sails. Certainly, the number of attacks has ebbed and flowed this century, reaching an earlier peak in 2008 and 2013, but the current wave of 
violence is greater in scope and deadlier. The number of crew kidnapped in the Gulf of Guinea increased more than 50 percent from 78 in 2018 to 121 in $2019 .^{20}$ Currently, the Niger Delta region accounts for the vast majority of global maritime kidnappings: it equates to over 90 percent of global kidnappings reported at sea, with 64 crew members kidnapped across six incidents in the last quarter of 2019 alone. The region accounted for 64 incidents, including all four vessel hijackings that occurred in 2019, as well as ten out of eleven vessels that reported coming under fire (Lumpur, 2020). As in South-East Asia, pirates in Nigeria used to confine themselves to raiding oil-tankers to sell their cargo on the black market. When the oil price fell after 2014, they began copying their Somali counterparts and focused on kidnapping crews, though oil theft made a comeback in 2018 and 2019. Unlike the Somalis, West African pirates rarely retain the vessels or the workers. Instead, armed with $\mathrm{AK}-47 \mathrm{~s}$ and knives, they storm a ship, round up some of the crew and return to land, where they hide their hostages.

Alternatively, if the prize is oil-and large quantities of oil that cannot be transshipped to the coast - then pirates engage in ship-to-ship oil transfer to a mother ship. Again, a different array of actors and rents are implicated. Pirates themselves do not have personal access to the networks with which to profit from the oil and typically deliver the oil to the principals for a flat sum. Once loaded to the tanker, the pirate groups are directed by the broker to deliver to specific locations along the West African coast and to oversee security while loading to tanks on shore. As Hastings and Philips (2015, p. 572) show, the boundary between licit and illicit has dissolved; the entities purported providing security are also involved in facilitating theft and providing protection: "the ship and cargo seizures are technically criminal activities, but at nearly every step of the way the pirates depend on the infrastructure (the ships, and storage and refining facilities) and the institutions (local brokerage, oil processing, and shipping companies, local and foreign buyers) of the formal oil economy." The visible and the invisible parts of the supply chain are in many respects indistinguishable. To add another layer of complexity, the kidnapping and piratical networks often overlap and intersect with other illicit maritime networks in the Gulf of Guinea especially drugs, human trafficking, and commodity smuggling (United Nations Office on Drugs and Crime, 2008; Ralby and Soud, 2018).

\section{The After-life of Oil}

What is the after-life of stolen crude? One answer is artisanal refining, locally known as "Kpo-fire." In virtually every community in the more isolated reaches of Niger Delta creeks and swamplands, households depend upon illegally refined fuels derived from stolen crude oil, typically selling at prices that undercut official fuel prices (see Garuba, 2010; Ikanone and Oyekan, 2014; Gelber, 2015). Plastic jerry cans of artisanal fuel (kerosene and petrol) are ubiquitous, retailing at roundabouts and markets even in large cities such as Port Harcourt or Warri. A small percentage of Nigerian crude is refined locally in state-owned refineries that are notoriously 
inefficient and typically lose vast quantities of money: over 12 months between June 2019 and 2020, the four state-owned refineries were idled and had operational losses of $\$ 367$ (Smith, 2020). The year previously they operated at 13 percent of capacity. As a consequence, virtually all refined oil products are imported and then sold at subsidized prices ( $\$ 0.48$ per liter), a sort of vast "permit raj" that was exposed in a House of Representatives report in 2012 that entailed illicit activity totaling $\$ 6.9$ billion, one of the most monumental cases of fraud in Nigeria's history (Mark, 2012; Sayne et al., 2015). A 200-page government inquiry revealed underhanded practices that fueled a sixfold increase in spending on oil handouts between 2009 and 2011. Fuel subsidies, part of a decades-old program meant to keep fuel prices low for millions of ordinary Nigerians, increased by 700 percent over three years. A report by a Nigerian House of Representatives committee identified the shadowy Nigerian National Petroleum Company-ranked the world's least transparent state oil firm-was single-handedly responsible for almost half of the siphoned subsidy funds and was "found not to be accountable to any body or authority." Seventy-two fuel importers, some with allegedly close links to senior government officials, were also singled out. In one case, payments totaling $\$ 6.4$ million flowed from the state treasury 128 times within 24 hours to "unknown entities."

If the oil import business represents another massive tranche of the system of oil theft-in which traders and "briefcase" companies fight over the rents-fuel shortages nevertheless abound, especially in remote delta communities. Diesel and kerosene are in short supply and at a premium. In impoverished creek communities in which there is a sense that the state (through nationalization) has stolen "their oil," the oil theft business was able to facilitate the emergence of what has become over the last decade a major growth industry. Every year, security forces claim to have destroyed literally hundreds and in some cases thousands of illegal refining encampments dotted across the creeks in the oil-producing states ${ }^{21}$. A report estimated that by 2018, some 43,000 barrels of crude were refined locally each day from roughly 500 camps; in two states (Rivers and Bayelsa) it was estimated that between 2013 and 2018 the number of refineries increased five-fold (to 2,500) driven in part by national fuel scarcity and a growing demand for diesel and kerosene, and also by new forms of investment associated with "informal business associations improved information sharing and coordination of the supply chain" (Stakeholder Democracy Network, 2014, p. 11; 2018, p. 4). As profitability has increased, new investors are bankrolling the camps and the distribution system, and a greater share of stolen oil now ends up on the domestic black market (roughly 70 percent). The value of illegal oil products in these two states alone was almost $\$ 1$ billion.

Illegal refining arose during the civil war (1967-70) among Biafran rebels cut off from fuel supply, but as oil theft began to proliferate in the 1990s and especially the early 2000s, so did artisanal refining. During 2003-04 as armed militia activity intensified, largely in response to state violence and the use by politicians and political Godfathers in the 2003 elections of armed youth groups and so-called cults to intimidate opponents. Competing non-state armed groups financed their 
activities increasingly through oil theft and refining. The leader of one important militant group (the Niger Delta People's Volunteer Force), Asari Dokubo, claimed that he had a tapped pipeline running to his compound and that his refined products - "Asari fuel"-were cheaper, better and more widespread in creek communities than commercial refined products. The bunkering territories are protected and indeed fought over while the security forces - the Navy and the Joint Task Force-simultaneously destroy illegal refineries while taxing their operations to ensure that the well-connected and wealthy refineries are protected. Especially since 2009, new refineries vastly outpace the rate at which refineries are destroyed.

Illegal refining depends on crude oil tapped from the tapping "unions" who deliver (and sell) the crude, often by Cotonou boats, to remote creeks' refining "camps." The distributors typically exclude middlemen and the vessels (and their work crews) can be owned by the tap owner, by larger refiners or by local transporters and vessel owners (Stakeholder Democracy Network, 2013). Distributors unload the crude either into open air pits or into so-called plastic Geepee tanks. An average camp might have ten to 20 people of all ages and genders; it requires capital investments (storage tanks, a "cooking oven," a cooling system and systems of hoses and drums). The refining process (dangerous for people and devastating for the environment) deploys a simplified version of fractional distillation in which crude oil is heated, condensed and separated. A camp operator (who might or might not be the owner) has workers, security, managers and "boatmen" in his employ. Tappers might earn $\$ 30$ per day, boatmen $\$ 50-150$ per day. Set-up costs for an average camp might be $\$ 5,000-6,000$ and might generate $\$ 7,000-8,000$ monthly in income.

The refining process uses a simplified version of fractional distillation (locally called "cooking"), in which crude oil is heated and condensed into separate petroleum products, aspects of which have been adapted from traditional gin and palm wine distillation. The illegal refining process yields diesel, petrol, kerosene, bitumen, and waste products. $^{22}$ The refining process begins when the "black" is heated in an "oven," burning crude oil to start the distillation, a process that releases dense black clouds into the camp, which, if not kept under control by spraying water onto the fire under the oven, can cause explosions. Distillation is kept cool through coldwater pumps and storage tanks, but the risks are substantial and the immediate impact on the environment catastrophic.

The illegally refined oil distributors typically represent yet another different network of actors and like tapping is one of the most profitable activities (in part because of the risks involved) in the oil theft assemblage. As the cost of buying stolen crude oil is a fraction of its true market price, the demand for cheap illegally refined products is considerable in both local and national markets. Most Nigerian crude oil grades are heavily diesel-rich but quality of refined products varies widely leading some refiners to purify diesel by mixing it with kerosene to improve the quality and launder the illegal product prior to distribution-much of which is sold in small quantities by women traders. Illegally refined diesel has become so intermixed with legal diesel distribution networks that it is impossible to say how far 
illegal products are being distributed, but there is a brisk trade in locally refined produce to other coastal states including Lagos. Locally, blended diesel is sold through pre-negotiated sales or along the roads or near filling stations and typically undercuts the official subsidized price of commercial fuels by fifteen percent or more. All movement and circulation operate under the cover of the police, the navy and military forces, and other security apparatuses. ${ }^{23}$

The major outlet for stolen crude is the international market. Barges of various sizes and conditions move the crude from the creeks where pipelines have been tapped-or in the case of theft at the export terminal simply add to the existing cargo in the tanker. Making their way downstream, pulled by tugboats, the barges meet awaiting tankers that, due to the topography of the Niger Delta, can anchor close to the places where the major rivers - the Benin, Escravos, Forcados and Ramos rivers-empty into the Atlantic. The vessels involved are typically in poor repair (but might cost from $\$ 50,000-75,000$, far beyond the means of most local oil tappers) and might have been officially decommissioned. The chain from theft up to transference to oil tanker or local distribution is handled by the same gang but generally different units of the same group whereas the operation of the oil tankers and marketing of the stolen oil overseas appears to be handled by separate entities. While there are dedicated security forces devoted to surveillance and monitoring in order to apprehend bunkers, in practice few arrests are made and even fewer are prosecuted; in some cases, the tankers and their cargo mysteriously disappear. In 2003 Brigadier General Elias Zamani, then commanding a Delta peacekeeping force, was asked whether oil was being stolen by local people, the security forces, government officials, or an international element. His reply was: “All” (United Nations Office on Drugs and Crime, 2009, p. 22; see also Pérouse de Montclos, 2012).

Tracing stolen oil is virtually impossible for several reasons (Katsouris and Sayne, 2013). First, buyers of Nigerian oil load their cargoes onto tankers carrying crude from other oilfields, or even other countries - a process called "co-loading." For example, a trader might send a larger tanker to Nigeria to lift a 700,000 barrels cargo of Abo grade crude oil which then travels to the Forcados terminal, where it picks up an additional 300,000 barrels of Nigerian crude for delivery to Europe. Single tankers commonly carry multiple "parcels" of oil owned by different parties. The resulting full tanker-load of oil is called a "split cargo" and each parcel comes with its own bill of lading. Co-loaded and split cargoes, while perfectly legitimate, provide opportunities for bunkerers to disguise volumes of oil stolen at a terminal or in the field as a legal co-load. Mixed tanker-loads of stolen and legal oil are also rebranded as split cargoes by forging a separate bill of lading for the stolen portion. Second, complicated international delivery routes can hide stolen parcels. After leaving Nigerian waters, a mother ship carrying stolen crude can offload all of its cargo at a single refinery, offload parts of its cargo at different refineries, offload all or part of its cargo into storage, transfer all or part of its cargo STS to another vessel, or transfer all or part of its cargo STS to multiple vessels. Virtually all STS transfers of stolen oil probably take place further out at sea. Finally, export oil 
thieves blend stolen Nigerian crude with oil from other countries and with fuel oil produced in or outside Nigeria. A range of customers buy the adulterated goods once they are mixed onboard tankers or at sites onshore. Some is probably sold as bunker fuel for ships. And finally, there is the murky world of storage. Most traders place large amounts of oil into storage facilities around the world. This enables them to blend crudes or hold them until a particular market improves. Most oil storage is on land, but some floats at sea. Due diligence and reporting regulations vary by location. Selling crude oil into storage can allow sellers to disguise the oil's origins in future transactions. For example, an unscrupulous trader could receive a consignment of stolen oil into tanks it owns or rents, then blend or break it into smaller parcels. New bills of lading can be issued for each parcel when it is eventually sold, making less diligent buyers less likely to ask for an original bill of lading created in Nigeria.

In sum, diverted oil is also part of a transnational business - an oil mafia-linking the high-ranking military, politicians, business elites, security and regulatory forces, and domestic and foreign oil traders and shippers. The international oil companies have been an active part of this mix: local level employees often conspired with refiners and oil thieves, while corporate executives saw this rough and tumble supply chain and outright bribes as the price of doing business.

\section{Making Oil Circulate: Political and Logistical Orders and the Invisible Supply Chain}

Oil theft operations in Nigeria - as everywhere-entail a logistical and political order to tap, circulate, and distribute a variety of hydrocarbon products to local, regional, and international black markets. The dynamic shape of this assemblageincluding elite political actors, youth groups, local and international and stateowned oil companies, shipping companies, insurgents, military, and much moreis secret and elusive yet in some respects conducted in broad daylight. The fact that the movement of tankers, or topping up, or illegal refining can often operate openly and indeed through formal channels speaks to the fact that the "invisible" (informal/illicit) supply chain operates through the same channels and with similar actors as the "visible" (formal/licit) global oil and gas supply chain. The same actors can be, and often are, involved in both sets of activities. The boundaries blur, the functions overlap and intersect. Furthermore, the invisible supply chain has its own formality. In the same way that the mafia constitutes a particular sort of order-a set of forms and conventions and relations to state powers-so too does the oil theft assemblage have its unions, taxes, dues, settlements, and returns. There are, too, enforcement (extra-economic) mechanisms; and like the formal gas supply chain, oil theft entrepreneurs and actors respond to market, security, and political signals. The oil theft industry has its own lexicon: foremen, tappers, sponsors, investors, buyers, and traders. If the illicit oil supply chain is in many respects coterminus with the licit-with considerable porosity between the two-this observation questions the view that the resource curse is simply a reflection of the fact 
that at every step from extraction to final export, as Hastings and Phillips write, "oil firms are potentially subject to rents extracted by local political actors, both at the national and local levels, and must pay them off or establish informal understandings with them-often they must do both" (Hastings and Philips, 2015, p. 572). This is both true and incomplete since oil firms are not simply complicit but are active agents in not just the extraction of value through rents but in the reproduction of the entire system. The licit and illicit systems of petro-capitalism are deeply imbricated and mutually self-sustaining, feeding off each other and exhibiting remarkable durability over time even in the face of conflicts and violence.

Much of this shadow economy remains elusive and our understanding remains incomplete. It is elusive not only because of secrecy and complicities at the highest levels of the state and government, but also because of the incomplete picture of the oil theft enterprise. The fullest report claims that the oil-theft supply chain is more cellular than hierarchical (Sayne et al., 2015). If Nigerian politicians and the press speak of bunkering barons and kingpins, or describe oil-theft rings as mafias or syndicates, they argue that "most export operations are probably not run by one person, family, or ethnic group, and management tends to be more cooperative than based on command-and-control" (Sayne et al., 2015, p. 6). But these are surmises rather than conclusions since there seem to be mafia-like consortia, of differing degrees of complexity and organization, operating at multiple levels. But it is clear there is considerable heterogeneity across the cells' networks membership; they vary the size and location of operations, needs and political entanglements. Actor influence and positions might wax and wane (military commanders come and go) but there is "a common set of roles to fill...high-level opportunists, facilitators, operations, security, local transport, foreign transport, sales and low-level opportunists" (Sayne et al., 2015, p. 6; see also Balogun, 2018). If this sounds like a fractal landscape that constantly shape-shifts, that is for now at least as robust a generalization as we can make of this oil assemblage and the operations of capital.

Oil theft in my account is restricted to oil products stolen from nodes within the logistical infrastructure and various rents extracted around these operations. But theft is widespread in other hydrocarbon domains that are arguably of equal if not greater significance as regards illicit proceeds. One area pertains to illicit financial flows around the awarding of oil licenses and bonus payments through the leasing and tendering process. Licenses are assets that are traded among the political and business classes and represent one of the least transparent aspects of the industry, and the most corrupt (Sayne et al., 2017). Another is sales and so-called "first trades," namely NOC-buyer contracts and terms of trade (which I turn to next) (Extractive Industries Transparency Initiative, 2015; Longchamp and Perrot, 2017). And another is revenue collection and distribution (royalties, taxes and public financial management) and the public procurement contracts issued for oil and oilrelated activities to oil-service companies, and so on (Organisation for Economic Co-operation and Development, 2016). These arenas are replete with all manner of value extractions - rents - of the sort I describe in my account of oil bunkering, and often on a vast scale. ${ }^{24}$ In fact there is an entire industry and an edifice of 
regulatory authorities devoted to documenting the scale of the graft and theft associated with illicit flows in these other domains of the planetary oil assemblage, including the EITI, OECD, and advocacy organizations such as Global Witness and the Center for Research on Multinational Corporations Here, the assignment and use of property rights often resemble outright theft: oil prospecting and oil mining leases are acquired by members of the political class and are bought and sold as an asset class; massive bribes are paid to secure mega-engineering contracts; buyer-trader licenses are in effect licenses to print money. And not least, there is outright theft - pillage really — at the highest levels of leadership. During the late military period in Nigeria, the stolen assets sent out of the country by President Abacha to offshore financial centers were estimated at $\$ 5$ billion, and the process has continued (especially in the period after 2009). Nigeria has no monopoly here. The infamous Bien Mal Acquis case affair involved a series of corruption scandals which emerged in oil-and-mineral-rich central African states in 2007. More recently, we saw the Luandagate affair ${ }^{25-}$ and revelations about so-called "oilygarchs" in the Paradise Papers and Wikileaks. While the theft involved in these instances turns on corrupt political elites, the role of the national oil companies - the black holes of any national oil sector-and international oil companies and trading houses is central to any understanding of the scale of financial hemorrhaging from the public purse.

Nigeria's universe of stolen oil returns us to Lefebvre's observations on global capitalism and space. First, oil theft is constituted through a myriad of overlapping, nested and intersecting spaces (the system is deeply territorialized): from bunkering territories, to oil concessions, to pipeline networks, to trade corridors, oil host community territories, military jurisdictions, and so on. All are more or less regulated and orderly; each has some form of quasi-sovereignty and is populated by its own petty sovereigns. It is a space of hypercomplexity overlaid with layered forms of sovereignty (in which state, corporate and forms of petty sovereign abound). Second, Lefebvre referred to a particular form of what he called state capitalism to understand the growth of post-war European capitalism and the complex spatial hypercomplexity. What is on offer in Nigeria and the licit/illicit value chain is less a version of pur et dur neoliberalism than a variant of oil-fueled state capitalism.

Two final points. Nigeria has no monopoly on oil theft: Russia, Colombia, Iraq, and the Caucasus are known to have significant losses, especially in downstream fuel theft. The fuel-smuggling trade is vibrant across the Turkish border to Syria. In the eastern Mediterranean, there is a flourishing smuggling of oil focused on Libya, Malta, and Cyprus. In 2018 a major oil theft occurred in a Shell refinery in Singapore, the company's largest refinery in the world. In Indonesia, there were 63 cases of oil theft from pipelines from one concession, the Rokan Block managed by Chevron Pacific Indonesia. And in Europe, pipeline theft grew from barely a few cases in 2010 to some 150 cases in 2015.

Mexico represents an intriguing case providing a sort of counterpoint to Nigeria both in terms of scale and organization. The country is a major oil producer and exporter of oil, accounting for fifteen percent of exports and twenty percent of 
state revenues, and like Nigeria has a large, complex national oil company (Petroleos Mexicanos, or PEMEX) controlling the upstream and downstream sectors. But oil theft (robo de combustibles), illegal oil traders (huanicoleros), and pipeline taps (tomas clandestinas) have grown from a cottage industry run by local gangs during the 1980 s and the 1990s into a massive industry in the hands of cartels and specialized huachicolero syndicates who violently compete for control over the trade. Centered on two "Red Triangles" located in Puebla and Guanajuato, with secondary centers in Veracruz and Tamalaulipas, by 2019, 22 states had reported oil theft (Sullivan, 2012; Duhaukt, 2017). In 2006 there were 213 illegal pipeline taps; by 2016 they had grown to 6,873 (accounting for over $\$ 11.3$ billion for the period 2009-2016). By 2018 the number of taps had almost doubled to a staggering 12,582 (Jones and Sullivan, 2019). Of the 1,533 pipeline taps reported in 2016, 1,071—or 70 percent of the total-were located along Highway 150D that parallels the trunk pipeline for refined products from Veracruz (and its refineries) to Mexico City. Not only was PEMEX itself in crisis, but oil theft and the violence it generated in a country marked by a pre-existing cascade of homicides (some 35,000 in 2019) reached crisis proportions. Oil theft in fact became one of, if not the, defining features of the first year on President Andres Manuel Lopez Obrado's sexenio following his landslide victory in July 2018.

Mexico's oil-theft assemblage reflects a rather different architecture to that of Nigeria, rooted as it is in the political history - and the political settlement - of post-revolutionary Mexico. Refined products (gasoline, diesel, kerosene) rather than crude represent the illicit commodities that are trafficked, and the focus is on a massive underground system of distribution (and to a degree larger scale refining) designed to undercut official fuel prices. ${ }^{26}$ Energy reforms put in place by the Nieto administration (2012-18) permitted oil prices to rise and incentivized huachicoleros to undercut the formal market system. More crucially, while there are extremely porous boundaries between the military and security forces, the NOC and the oil thieves (like Nigeria), the central players in Mexico are transnational drug cartels that came to oil theft late in their institutional careers (the 2000s) on the backs of the deepening role of Mexico after the 1980s in the global cocaine, heroin and other narcotics wholesale trade. In part because of the anti-drug policies on both sides of the border and the changing markets structures for drugs, the cartels diversified and moved into oil theft, for which their national and transnational trade networks could be easily repurposed (Correa-Cabrera, 2017). The territorial natures of the cartels, their constant fragmentation and division as a result of the Mexican government's kingpin strategy which produced intra- and intercartel violence, and the geography of the PEMEX pipeline networks meant in practice a ferocious and violent struggle between cartels and other subsidiary or independent fuel traffickers to control the fuel business. And not least, the fuel cartels_ currently the fuel trade is dominated by Cartel de Santa Rosa Lima, the Cartel Jalisco Nueva Generación, and the Los Zetas cartel (a splinter group of the Gulf Cartel)—used their pre-existing military capabilities to extort and threaten PEMEX workers (to access pipelines, refineries, liquefied natural gas storage tanks 
and even offshore rigs), secure protection from the military and the judiciary, and develop a national (and cross-border to the United States) tanker distribution system quite unlike the Nigeria domestic black market. The Mexican cartelized theft system is marked by extraordinary violence even by Nigerian standards: cities like Salamanca which houses a large refinery and the PEMEX Minatitlan Mexico City pipeline have been marked by extraordinary bloodletting and conflicts between the cartels and gangs and by period pipeline explosion involving hundreds of casualties.

Reading Mexico's oil theft history against that of Nigeria throws up some obvious parallels in terms of state capture and the complicities among the state oil companies, security forces, political classes, and oil thieves. But the actors, processes, and differing political histories and political settlements in each petro-state shape the specific forms in which the oil assemblage operates and reproduces (Hickey and Izama, 2017). Oil theft grew out of and was captured by drug cartels that were at the time a product of both the changing global character of the drug trade, the nature of the drug markets, and the declining powers of the then-ruling party, the Institutional Revolutionary Party (Correa-Cabrera, 2017). Nigeria's theft, by contrast, grew out of a political settlement in which an elite cartel presided over a provisioning system and a multi-ethnic federal system (Roy, 2017; Porter and Watts, 2017). For complex reasons, the systems fed popular resentments on the oilfields that resulted in the proliferation of armed non-state groups and ultimately an armed insurgency and amnesty. These histories color the oil-theft assemblages while retaining family resemblances. Interestingly, in a way that has no obvious parallel in Nigeria, the election of left populist President Obrador unleashed a major assault on the oil-theft sector both to stop the loss of revenues and also to stabilize a crippled PEMEX, reduce the extraordinary violence, and provide a better environment for investment by international oil companies. By mid-2020 it was reported that oil theft had decreased by 90 percent and in August "El Marro," the head of the Cartel de Santa Rosa Lima, was captured by Mexican security forces (Dalby, 2020).

Finally, oil and gas, like most supply chains, disclose the fact that "the trappings of logistical giants in one place actually hinge on logistical work in utterly deregulated zones elsewhere" (Schouten et al., 2019, p. 780). These are the circulation struggles - the imperatives to control place, space and territory and what moves through and across it-which do not produce a clean logistical space, a well-ordered supply chain in which place has been thinned out or eviscerated. Quite the reverse. Forces of calculability and order fulfill "disorderly" functions and vice versa. They are organically and dialectically related and constituted. These two faces of the oil life world - and the porosity between them-constitute an important expression of the oil cosmos but of so many global supply chains as the contributions show. Logistical orders can be and regularly are disrupted, blocked, diverted, and appropriated in novel and creative ways, and all of this points to the co-production of logistical and political orders. Making things move and circulate is both an expression of power and constructs and depends upon systems of public and private authority. 
Oil theft reveals powerfully how the intersection of logistical/infrastructural and political orders constructs ontologies — what Julian Reid (2006) calls logistical life-within the vast oil assemblage. These logistical and infrastructural orders, as uneven and irregular as they are over space, create different opportunities and different kinds of space "because they create the thickenings of publics, and offer the possibility of assembling people or slowing them down" (De Boeck, 2012). Oil theft is built in and through oil infrastructures and represents what I call an "oil cosmos": not a circumscribed enclave of social thinness but an entire lived world. As a measure of this cosmos one only need note that the very presence of oil infrastructure (a wellhead, a pipeline) confers an existential status on communities: when present in a community territory a village or town or city neighborhood becomes an "oil host community" which confers particular rights, rents and identities. Of course if there is something of the entrepreneurial spirit at work in oil theft networks, and of resistance too (popular appropriation by those who see their oil resources as having been taken from them), it is a world of violence, conflict, subterfuge, and precarity. It is an ambient and combustible world, a vast provisioning machine in the business of shaping human experience and social identities. It is a sort of sensorium.

\section{Logistics, Finance, and First Trades: Contract Theft and Commodity Traders $^{27}$}

The circulation of large quantities of stolen oil points to one of the great unexplored domains of the oil and gas assemblage: namely, so-called "first trade" between NOCs and buyer-traders, and specifically the role of the private commodity-traders, finance capital (on whom the traders rely) and not least the shady world of shipping and maritime movement. Value extraction and rent-seeking abound in this world, and I can only offer here the briefest of glimpses with the aim of shining light on the links among extraction, finance, and logistics and on the degree to which the planetary well turns on marginal, liminal, and frontier spaces that are not so much on the oilfields - frontiers though they might be-but in in the capitalist world of banks and offshore finance and in the great (and spectral) world of trading contracts. These are populated not only by the trading divisions of the international oil companies but more crucially by the likes of Glencore, Koch Industries, Mercuria, Trafigura, and large independent commodity traders.

Until recently, the trading system, and the relations between government sales and private buyers, have been strikingly absent from transparency measures and very little research has systematically focused on illicit flows arising from first trades. This interface is the key moment at which oil produced (that is to say the upstream sector) enters the global market (the midstream sector) with its price tag. First trade or equity oil is acquired by a considerable variety of buyers and traders-from international oil companies with their large trading desks to the large commodity trading houses, small independents, and even other national oil companies. Commodity-trading firms are essentially in the business of transforming commodities in space (logistics), 
time (storage), and form (processing). Their basic function is to perform physical "arbitrages" which enhance value through these various transformations.

The scale and scope of oil trading and their significance for oil-producing states and their treasuries are substantial. In 2014 the Berne Declaration-now known as Public Eye-and Swissaid analyzed the oil sale activities of the top ten oil exporters in SSA and found that from 2011 to 2013 the governments of these countries generated more than $\$ 250$ billion in sales revenue, equaling 56 percent of their combined government revenues (Gillies et al., 2014). A NRGI National Oil Company Database released in 2019 analyzed the oil, gas, and product sales by NOCs in 35 countries for which data is available and revealed that the first trades made by NOCs in these 35 countries to commodity traders and other buyers generated over $\$ 1.5$ trillion in 2016 (22 percent of total state revenues). Updated oil sales data for 2016-18 available for 28 countries indicate that government revenue generated from commodity trading has risen significantly, from $\$ 1.4$ trillion in 2016 to $\$ 2.1$ trillion in 2018 .

The scale of revenues generated from oil sales, coupled with the lack of regulation of how these sales are conducted, creates enormous opportunity for value extraction and rent-seeking. According to Global Financial Integrity, unrecorded oil sales amount to 17 billion annually (500,000 barrels per day) (McHugh, 2012). In 2016 OECD published a study that analyzed 131 corruption cases involving foreign public officials in the natural resources sector, including trading. Significantly, 26 of the cases (20 percent) appeared to involve commodity trading. These figures refer only to the number of cases, not to the sums of money misappropriated. If the latter were considered, then the scale of corruption in the trading phase, measured in terms of financial flows, would be greater still. Trade corruption involving Vitol, Philia, and Gunvor in the Democratic Republic of Congo, and Glencore in Kazakhstan, have been well documented (Public Eye, 2017). On February 26, 2020 the Swiss Federal Council published a report, Supervision of commodity trading activities from the point of view of money laundering, written in response to a postulate by the Council of States, that recognizes the high risk of corruption to which the commodity trading sector is exposed (Swiss Federal Council, 2020). The Money Laundering Communication Office (MROS) shows that over the past ten years, several thousand suspicious transactions related to trading have been reported. Two major international corruption scandals involving Brazilian and Venezuelan oil companies (Petrobras and PdVSA) alone resulted in more than 1,500 reports between 2015 and 2018. For the report, MROS evaluated a sample of 367 communications on suspicious transactions linked to trading between 2016 and 2018 (without taking into account Petrobras, PdVSA and other "laundromat cases"). These related to around 1.1 billion francs. MROS identified trading in fossil fuels as particularly risky, accounting for 85 percent of the samples examined. In addition to consulting companies and trust companies, the report mentions real estate companies and pension funds, in which profits are suspected of being of criminal origin, and which are said to have been reaped as part of raw materials trading activities. It concludes that "the Swiss financial center, given the 
size of the sector, is particularly exposed to the risk of money laundering linked to commodity trading, both through its banks and through traders established in Switzerland" (Swiss Federal Council, 2020, p. 9).

The menu of trading risks is broad, including not only the potential for tax evasion and money laundering associated with mis-invoicing but also the possibility of bribery, collusion, and below-market pricing associated with the largely opaque oil-backed loans and oil-for-product swap agreements. In Nigeria, for example, a number of beneficiaries of export allocations are nothing but letterbox companies whose sole function is that they are linked to high-ranking political officials or their entourages. Politically linked holders of "letterbox" or "briefcase" companies have, as the Nigerian Task Force explained, little or no commercial and financial capacity. In Nigeria, such fake entities represent a major part of the "oil market." As pointed out in a Chatham House report, only 25 percent to 40 percent of the holders of export allocations actually have the capacity or will to finance, ship, and sell their cargoes directly (Katsouris and Sayne, 2013, p. 8). The entire trading system attracts shadowy idle men, because these companies belong to individuals serving as fronts for the political class and power brokers.

First trades have been linked with a class of risks surrounding resource-backed loans (RBLs), namely loans provided to a government or a state-owned company, where repayment is either made directly in natural resources, (that is, in kind, or from a natural resource-related future income stream), or repayment is guaranteed by a natural resource-related income stream, or a natural resource asset serves as collateral (Mihalyi et al., 2020). RBLs are simply one set of transactions linking buyers and NOCs, but they carry significant risks because of their size and opacity. NRGI's analysis demonstrates that RBLs are remarkably opaque (only in a single case was the key contract document public) and they carry immense major public finance risks, as reflected in the fact that of $14 \mathrm{RBL}$ recipient countries, ten experienced serious debt problems after the commodity price.

Although all commodity traders engage in transformation activities, they are tremendously diverse. Switzerland, which is the world's leading commodities trading hub with an estimated 35 percent share of the oil market, has over 500 trading companies, almost 90 percent of which are private; 42 percent had fewer than ten employees and ten percent more than 300 (Ascher et al., 2012; Pirrong, 2014). The five largest Swiss independent traders (Vitol, Glencore, Trafigura, Gunvor, and Mercuria) typically trade almost 18 million barrels per day, equivalent to about 20 percent of global demand. There is no common pattern in terms of the commodities they trade and transform, in the types of transformations they undertake, in their financing, and in their forms of ownership. Traders and sellers are often linked through complex financial and joint-venture agreements. The trading assemblage is diverse not only in virtue of the nature of the sale contracts and price negotiations, but also because of the relations and networks linking companies, buyers, finance capital, audit houses, and credit rating agencies. In engaging in these transformation activities, commodity traders face a wide array of risks, some of which can be managed by hedging, insurance, or diversification, but 
they face others that must be borne by the firms' owners. On a global canvas, much of the trading activity is centered on a cluster of global trading hubs (the UK, the Netherlands, Singapore, and Switzerland). Overall, the oil trading system is one of the most complex attributes of the global oil assemblage.

International oil companies - for example BP, Shell, Total-with their own trading desks sell their own production but also buy and sell third-party production. As "asset-based traders" they have access to and frequently use their own capital to fund trading activities. BP, Shell and Total alone traded 15 million barrels of crude a day in 2016. Independent international commodity traders are generally companies that have not traditionally engaged in production, are often privately held $^{28}$, and typically deploy bank-provided trade finance to fund their trading activities. Many of these companies are based in Switzerland, the UK, Dubai, and Singapore. Domestic buying companies operate only in the producing country and are heterogeneous in their scale and operations. Some are large and established, others are more akin to "middlemen" or "briefcase" companies acting as intermediaries between the NOC and other larger buyers. National Oil Companies whose subsidiaries trade in commodities either produced by themselves, or by third parties (e.g. China's Sinopec and Azerbaijan's SOCAR). Finally, there are the investment banks that trade commodities, such as Goldman Sachs and Citigroupthe number of which has fallen dramatically due to bank regulatory changes after 2008-and the end-users such as refiners, smelters, and processors (e.g. Sinopec, Japanese refiners such as JX Nippon Oil, and Energy Corp.). Traders generally do not have fully integrated supply chains and are lighter on assets, instead chartering vessels and entering into joint ventures with local counterparties. All traders depend upon liquidity and loans, typically through a suite of instruments to manage financing and settling of accounts that might include, for trader-NOC trades in particular, opaque and complexly structured crude-for-product swaps, oil-backed loans, or off-take agreements.

Viewed through the lens of the planetary well, the global oil trading system is intricate and byzantine, composed of varied assemblages of actors with contrasting interests and positions within a commodity system operating across multiple regulatory jurisdictions. In systemic terms, commodity trading is arguably one of the most complex and difficult to regulate within the oil and gas value chain. The trading system is dynamic, market prices are capricious, and risks are legion; this is not least because the architecture of the system has changed, and is changing, in relation to global capitalism in its recent financialized forms, and in response to market volatility and global competitive pressures. Over the last four decades, the system has experienced a thorough-going financialization (Gkanoutas-Leventis and Nesvetailova, 2015; Gkanoutas-Leventis, 2017). The 1980s liberalization and the institutional changes in the market triggered by the launch of commodity indexes by financial institutions in the early 1990s contributed to the growth of futures contracts and a raft of new actors. But recent market developments spurred by the introduction of permissive regulations in 2000 with the launch of the Commodities Future Modernisation Act in the United States opened the oil commodity markets 
to mutual funds, insurance institutions, and banks. Some of the largest investment banks, later known as "Wall Street Refiners," established specialized departments for trading in the oil market. By 2003 most of the biggest U.S. hedge funds were engaged in commodity markets, their involvement tripling between 2004 and 2007.

As oil became an increasingly popular asset class with investors, it widened the opportunities for hedging but also for financial speculation. Furthermore, the advance of financialization and the integration of financialized markets through indexification, produced endogenous dynamics in this market creating new sources of fragility and risk. Sometimes called "oil vega," this financialization of oil and the rise of paper trades made oil prices both volatile and largely independent of physical trades and market fundamentals. At the same time, despite the plethora of regulatory agencies in global finance, regulatory arbitrage is a defining quality of the global financial system, permitting commodities markets to thrive in between regulatory niches, capitalizing on permissive regulatory policies nationally, and exploiting unregulated spaces internationally (Gibbon, 2004). Most traders operate in and through trading hubs or offshore financial centers associated with favorable regulation and tax rates, strong capital markets, a deep tradition of trade and shipping and human capital resources (London, New York, Chicago, Houston, Calgary, Tokyo, Hong Kong, Geneva, Zug, and more recently the UAE and Singapore). Traders might be involved simultaneously in the buying, selling, transportation, storage, and refining of physical oil yet at the same time in value terms the overwhelming majority of trades are in so-called "paper trades" (the futures and derivative markets). In this huband-spoke network system, populated by a diverse suite of buyers, traders, and financiers, it is the opacity that presents such a challenge to anti-IFF measures.

The oil trading assemblage is not just complex, variegated, global and multiscalar in its operations. It exhibits a number of distinctive structural properties, three which are key for my purposes. First, the extent of operations that make use of offshore financial centers (OFCs) and subsidiaries that have ambiguous functions. Second, the lack of opacity in the trades themselves. The trading system seems to seek out, and even reproduce, opacity, operating in frontier-like (unregulated) spaces both within the oil producing states themselves but also in the trading hubs and OFCs. And third, increasingly the role of deregulated banking functions (KPMG, 2015). A blend of low commodity prices, deepening competition, capital requirements, and increased price transparency has eroded margins, reduced arbitrage opportunities and modified the players participating in this competitive arena. In addition, new banking regulations have also changed the financial architecture of the trading system. Large commodity trading houses have become active in the financial and credit markets, extending credit to economy and becoming part of the unregulated segment of the financial system, or the shadow banking system in large part because of the withdrawal of the larger investment banks as a consequence of regulatory changes in the financial sector most (notably Basel III, Dodd-Frank, MiFD II). Increasingly, smaller banks with a higher risk appetite are coming to the forefront, including Chinese banks looking to participate in 
syndicated facilities while hedge funds, private equity and specialized trade finance funds are incrementally being used by commodity traders as financing alternatives. All this makes for a world that lacks transparency, is shrouded in secrecy, and often operates in the shadows.

A stock-take of first trade transparency by EITI in 2018 revealed that of fourteen countries reviewed, over half did not provide core information by the seller, and virtually all buyers failed to disclose information on contracts, beneficial ownership, loading points, or buyer selection processes (Extractive Industries Transparency Initiative, 2018). The first pilot reports reveal both the limited impact of disclosure requirements and the contentiousness of the regulatory domain itself. Engagement by traders has in general been very low (and some of the Chinese and Russian buyers and financial houses are for the most part beyond the reach of EITI); the data is uneven in detail and quality and often inconsistent in what is measured. Contract disclosure is almost wholly absent, and beneficial ownership data is missing in cases such as Nigeria where there is a strong emphasis on local buyers. In Nigeria, 66 of 73 companies did not submit the reporting templates and as a result were unable to reconcile 81 percent of NNPC crude sales (Nigeria Extractive Industries Transparency Initiative, 2019).

Nigeria is, once again, a textbook example of value extraction through NOC-buyer contracts where the selection of buyers, the allocation of buyers' rights, and the negotiation of the terms of sale are shrouded in secrecy. The entire arena of contracts (for licensing and exploration and for oil-related engineering and service work) is the most opaque of sectors. The Nigerian case is so complex because virtually all sales are mediated through middlemen, and because the scale and size of the cargoes is vast. Conversely, in 2017 Nigeria sold 453 cargoes to 61 buyers totaling $\$ 13.2$ billion, including Glencore, Trafigura, BP, Total, NNPC's trading subsidiaries (Duke Oil, Carlson Bermuda), and domestic buyers (Sahara Energy), including a number that are seemingly shell companies with no palpable operations, and foreign national oil companies (SONAR, SINOPEC). New research is gradually exposing not only the shady oil swap and oil-for-product deals and the key role of the major trading houses, but a much wider landscape of complicities between rogue Nigerian middlemen and enablers, and the diverse world of oil traders, speculators, and financiers (Berne Declaration, 2013; Gillies et al., 2014; van Drunen et al., 2020) Politically exposed letterbox companies, secret calls for tender, opaque and shady partnerships, and links between Nigerian importers of refined fuels and Swiss trading houses (making use of the fuel subsidies discussed earlier) are all part and parcel of the normalized operations of the trading houses.

The intensive use of Offshore Financial Centers, particularly by independent traders, combined with the complexity of corporate holdings through OFC jurisdictions, weakens the system of corporate governance at the same time as the relatively light touch and willful laxity of oversight by public authorities is a key point of attraction for corporate managers. However, banking regulations and the withdrawal of formerly dominant international banks from directly financing trades has seen the rise of local banks and traders and joint venture arrangements - a trend 
that has increased the relative difficulty of establishing the bona fides and identity of counterparties to the deal. In turn, this is reported to be weakening the effectiveness of corporate governance protocols where incentives exist for them to be applied. The oil-trading system in this sense has its own differentia specifica compared to other sectors of the oil and gas value chain.

\section{Frontiers Across Planetary Oil}

Capitalism is a frontier process.

Jason Moore, Capitalism in the Web of Life, 2015, p. 107

I want to conclude with a word about commodity frontiers and planetary oil. To the petro-geologist, the frontier has a set of technical meanings. It is a geological province which becomes a working petroleum system, a play with its own unique reservoir properties, particular temperatures, flow characteristics, viscosity, and so on. In another sense, as a geological formation located in space-and therefore located within the supply chain - these plays are often at the margins and fringes of the global value chain opening and closing with the shifting horizons of the exploration and production process of the oil industry. Much of my account focuses on these frontiers in the rough-and-tumble terrains, the "fragile and conflicted" petro-states of the Global South marked by "poor governance." To this extent, the oil frontier represents a particular sort of social space. Frontiers are sites within the global supply chain "beyond the sphere of routine actions of centrally located violence producing enterprises....[populated] by classes specialized in expediency whose only commitment [is] to preserve the order that made possible the profitable utilization of such expediency" (Baretta and Markoff, 2006, pp. 36, 51). Frontiers are social spaces at the limits of central power where authority-and indeed the rule of law and its forms of enforcement and oversight-is neither secure nor non-existent. The key attribute here is institutional patchiness or unevenness, or what James Ron usefully distinguishes as weakly institutionalized spaces not tightly integrated into adjacent core states (Ron, 2015, p. 7). Oil frontiers in this sense do not necessarily conform to Tsing's (2005) much-cited view that frontiers are unpredictable, free for all, not yet mapped, unstable. In my view this is not quite right: frontiers can stably reproduce, and their dynamics frighteningly predictable and ordered. As Grandin (2019) says of the frontier, the state often precedes it; authority, power, and institutions of all sorts are present in complex and differentiated ways. Put differently, the characteristic of frontiers everywhere is the circumvention of infrastructural and administrative grids of the formalized economy.

The world of oil theft and invisible-visible supply chains shows how across the space of planetary oil are all multiple frontiers some of which are located at the other end of the oil assemblage, in offshore financial centers populated by shell and dormant companies and consolidated and encased by law, financial institutions, audit companies, and the like. As the world of oil trading shows so clearly, that part 
of planetary oil is no less subject to opacity and lack of transparency than oil theft or the byzantine operations of national oil companies. The trading houses and trading desks, offshore financial centers in the Cayman Islands, Luxembourg, Bermuda, Hong Kong, the Netherlands, Ireland, the Bahamas, Singapore, Belgium, the British Virgin Islands, and Switzerland are also part of a great cosmos of oil theft and hyper-extraction. In some of these frontier settings, extraordinarily capable expertise and regulatory capabilities are brought to bear to limit the reach of public authority. It is not only in the oil producing states that "old margins are becoming new frontiers" but also in places like Singapore and Zurich "where mobile, globally competitive capitals find minimally regulated zone in which to vets its operations" (Mezzadra and Neilson, 2019, p. 123).

In planetary, hyper-extractive systems frontiers open and close over time and space. Frontier phenomena, which populate supply chains everywhere, are marked by institutional patchiness, by overlapping and complex nested forms of power and authority. Sometimes frontiers might throw up alternatives - counter-logistics or even emancipatory political orders-but as often as not they are precarious, violent, and illicit. Frontiers point to the fact that the infrastructural and political orders that operate across and through planetary oil might operate in close proximity to, or in conjunction with, the state or they might exist largely outside of it. Perhaps this is what Bertolt Brecht (1927) had in mind when he wrote in his poem 700 Intellectuals Pray to an Oil Tanker that "God has descended again in the form of an oil tanker."

\section{Notes}

1 I would like to thank Doug Porter for many conversations on these topics and the recent OECD research teams on illicit finance and the oil sector. Judith Shapiro provided much-needed input and editorial guidance.

2 The issue of oil and gas data — or more properly epistemology—is extremely murky. Figures produced by state, corporate, and advocacy organizations on the number of spills, their cause, and the volume of spillage, to say nothing of output and revenues, vary enormously. It is emblematic of larger questions about transparency and the degree to which the most basic information-for example, wellhead and export terminal metering systems - are either non-existent or are inadequate and/or tampered with. For an industry marked by technological complexity and sophistication, the appalling quality - to say nothing of the elasticity — of the most basic data is striking (see Watts and Zalik, 2020).

3 Spatial complexity is matched by various oil 'temporalities' (pertaining to the duration/ longevity of the reservoir, time to first or peak oil, length of concession and so on) and 'verticalities' (pertaining to petro-geology, well depth, land or sub-sea based reservoirs and the like). See Lunning (2018), Woegink (2018), and Yusoff (2017).

4 Materials are taken to include biomass, fossil fuels, metal ores, and non-metallic minerals. Primary materials refer to those sourced from mining and extraction activities in their raw form, such as mineral ores. Secondary materials refer to materials that have been used previously (i.e. recycling). See UNEP 2019 Global Resources Outlook: 2019. Nairobi: United Nations Environment Program, p. 42.

5 Resource extraction and processing make up about half of the total global greenhouse gas emissions and more than 90 percent of land- and water-related impacts (biodiversity loss and water stress). 
6 In his memoir A Promised Land (2020) President Barack Obama emphasizes how the novelty and enormity of the Deepwater disaster shook him. Until then, Obama had maintained a "fundamental confidence" that he "could always come up with a solution through sound process and smart choices." But those plumes of oil- "emanations from hell"-rushing out of a cracked earth and into the sea's ghostly depths" seemed of another order, unassimilable to his generally imperturbable worldview.

7 They pull upon the work of Lauren Benton (2010) to emphasize the forms of quasi- or partial sovereignties, and the world of non-state world of petty sovereigns, to expose the fragmented and uneven complexities of contemporary capitalism. In a somewhat different register, albeit more sensitive to racialized extraction, Macarena Gomez-Barris (2017, p. 1) offers a decolonial theoretical account "foregrounding submerged perspectives" anchored in "anarcho-feminist indigenous critique."

8 The proliferation of these rents means not only that they are the basis of capitalist expansion but are the objects of contest and struggle over, for example, which group elites receive import licenses, which ethnic groups are awarded mining leases, and who benefits from corporate community development projects.

9 A research project involving myself, Alexander Arroyo, Arthur Mason, and Berit Kristofferson entitled "The Digital Arctic" is currently in progress.

10 Almost 5 million producing oil wells puncture the surface of the earth $(77,000$ were drilled in 2019, 4,000 offshore); 3,300 are subsea. There are by some estimates over 40,000 oil fields in operation, more than 2 million kilometers of pipelines blanket the globe in a massive trunk-network and another 75,000 kilometers of lines transport oil and gas along the seafloor.

11 Subsea exploration in the Barents Sea has been challenged in Norway on legal and environmental grounds (www.nytimes.com/2020/11/05/world/europe/norway-supremecourt-climate-change.html), but the new Arctic has also meant explosive commercial competition among littoral powers (www.nytimes.com/2020/11/12/us/russia-militaryalaska-arctic-fishing.html).

12 The assets of the largest ten oil and gas companies is roughly $\$ 3$ trillion.

13 The latest trade data to estimate the magnitude of import and export trade misinvoicing-one of the largest components of measurable illicit financial flowsamong 135 developing countries and 36 advanced economies shows that by industrial sector, mineral fuels exhibited the second largest value gap $(\$ 113$ billion, representing 16 percent of total trade) between 2008 and 2017 (see Global Financial Integrity, 2020).

14 On 29 August, 2019 the Ad-Hoc Committee of the National Economic Council on Crude Theft disclosed that Nigeria lost about 22 million barrels in the first six months of 2019. This loss was later put at $\$ 1.35$ billion. This amount is already about 5 percent of the entire year's budget. Also, it is more than the capital allocations for education, healthcare, defense, and agriculture combined.

15 Cited in www.bloomberg.com/news/articles/2019-06-05/nigeria-s-oil-thieves-roar-ba ck-even-as-militants-kept-in-check.

16 In 2018, four pipelines-the NCTL, the Trans Forcados pipeline, the Trans Niger pipeline and the Obagi flowstation-accounted for 600,000 barrels of lost crude oil.

17 In this section of oil theft, I make use of fieldwork conducted in the Nigeria delta over the last 15 years and the following: Katsouris and Sayne, 2013; UNODC, 2009; Oyefusi, 2014; Fiennes, 2020; Naanen and Tolani, 2015: Schultze-Kraft, 2017; Ugor, 2013; Balogun, 2018.

18 A manifold is a more complex arrangement of piping or valves designed to control, distribute, and typically monitor oil and are often configured for specific functions that require a higher degree of control and instrumentation. A flowstation is usually the first stop for hydrocarbon fluids coming from crude oil and gas wells. Its purpose is to separate the hydrocarbon into liquid and vapor phases, reduce turbulence, and pass on the liquid to the next facility. 
19 Pipeline Surveillance Contracts in the Niger Delta, Policy Brief (Port Harcourt: Stakeholder Democracy Network) describes an archetypical surveillance contract or as follows: "through the network of relationships the pipeline surveillance contractor maintains across communities, he is able to neutralize such opposition by distributing 'royalties' to 'settle' with chiefs, elders, young people, and women's groups before work begins. These demands typically amount to $10-15$ percent of the value of the work to be done. He keeps track of the total amount of money that he distributes and that the international oil company reimburses him, depositing that amount into his bank account, using payments euphemistically known as "local content"” (Stakeholder Democracy Network, 2019:1).

20 In 2019, over 90 percent of globally reported kidnappings and hostage-taking at sea took place in the Gulf of Guinea, and the vast majority of attacks are launched on shipping from within Nigerian territorial waters: www.hstoday.us/channels/global/global-con cern-grows-as-gulf-of-guinea-piracy-attacks-increase-in-number-and-violence.

21 According to the Nigerian Navy, 2,287 refineries were destroyed between 2015 and 2019 with a peak of 1,218 in 2017: https://guardian.ng/news/nigeria/nigerian-na vy-destroy-2287-illegal-refineries.

22 After refining 30 drums of crude, a refiner might produce 25 drums of diesel worth N250,000; six drums of kerosene are worth N30,000 in the black market.

23 A recent Transparency International (2019: 4-5) report documented military personnel demanding payments, regular and scheduled, from illegal refineries in exchange for allowing them to operate have continued to surface. Interviewees in Bayelsa state, for example, reported that after an illegal refinery failed to meet a deadline to pay an "operational fee" of 4 million Nigerian naira $(\$ 11,000)$, military officers arrived on the site and opened fire, allegedly killing one person and demanding an extra 200,000 Nigerian naira $(\$ 550)$ for the delay. On the next day, 1.7 million Nigerian naira $(\$ 5,000)$ was delivered to military personnel with a promise to pay the balance of 2.3 million Nigerian naira $(\$ 6,000)$ later. Standard "tax" payments for each drum of product was 1,000 to 2,000 Nigerian naira ( $\$ 3$ to $\$ 6$ ), and retailers of illegal oil products spend an average of 60,000 Nigerian naira $(\$ 167)$ on transportation "settlements" for different security personnel, including the military, and police at road checkpoints if trucks were deployed to move the oil.

24 In 2008, Albert J. Stanley, a former executive with a Halliburton subsidiary (KBR), pleaded guilty to charges that he conspired to pay $\$ 182$ million in bribes to Nigerian officials in return for contracts to build a $\$ 6$ billion liquefied natural gas complex.

25 Isabel dos Santos, the daughter of former Angolan president José Eduardo dos Santos and Africa's richest woman, has a reported fortune of over $\$ 2$ billion. According to the Luanda Leaks, as well as reports from Maka Angola and other sources, Ms dos Santos and her husband earned some of their money thanks to public contracts approved by her father's government and suspicious deals struck with state-owned companies. Ms. dos Santos was appointed as head of Angola's national oil company, Sonangol, by her father in June 2016 and remained in place until she was removed by the current President in November 2017 (see www.icij.org/investigations/luanda-leaks).

26 As in Nigeria with some of the militants who steal and refine oil and supply local communities, the oil cartels have often gained popular support by provisioning cheap fuel, making gifts of fuels to poor communities to celebrate holidays, and by developing a huachicolero subculture that involves the adoption of Catholic saints.

27 Parts of this section draws upon research I conducted for an OECD project on Illicit Financial Flows and Oil Trading. I am grateful for the insight provided by the research teams including Catherine Anderson, Doug Porter, Alexandra Gillies, Joe Williams, Anastasia Nesvetailova, Ronen Palan, and Phil Culbert.

28 The exception in the top five trading houses is Glencore (revenues of $\$ 219$ billion in 2018; 158,000 employees), which is also now a major extractive company, following its merger with Xstrata, in the mining sector and owns limited upstream assets in the oil sector. 


\section{References}

Adunbi, O. (2015) Oil Wealth and Insurgency in Nigeria. Indianapolis, IN: Indiana University Press.

Amnesty International. (2013) Bad Information: Oil Spill Investigations in the Niger Delta. London: Amnesty International Publications.

Amnesty International. (2015) 'Niger Delta: Shell's Manifestly False Claims About Oil Pollution Exposed, Again'. Available at: www.amnesty.org/en/latest/news/2015/11/shell-fa lse-claims-about-oil-pollution-exposed.

Amnesty International. (2018) 'Negligence in the Niger Delta: Decoding shell and Eni's poor record on oil spills'.

Andreucci, D., García-Lamarca, M., Wedekind, J., and Swyngedouw, E. (2017) "'Value grabbing”: A political ecology of rent', Capitalism Nature Socialism, 28 (3), pp. 28-47.

Appel, H. (2019) The Licit Life of Capitalism. Durham, NC: Duke University Press.

Appel, H., Mason, A., and Watts, M. (eds.) (2015) Subterranean Estates: Life Worlds of Oil and Gas. Ithaca, NY: Cornell University Press.

Arboleda, M. (2020) Planetary Mine: Territories of Extraction Under Late Capitalism. London: Verso.

Arroyo, A. (In progress) 'Designing a digital ocean: Speculative oceanographies in the New Arctic,' PhD Dissertation, Berkeley: University of California.

Ascher, J., Lazlo, P., and Quiviger, G. (2012) Commodity trading at a strategic crossroad, Working Paper on Risk \#39. London: McKinsey \& Company.

Bala-Gbogbo, E. (2019) 'Nigeria's oil thieves roar back as militants kept in check'. Bloomberg. Available at: www.bloomberg.com/news/articles/2019-06-05/nigeria-s-oil-thie ves-roar-back-even-as-militants-kept-in-check.

Balogun, W. (2018) 'Crude Oil Theft, Petro-Piracy and Illegal Trade in Fuel', PhD Dissertation, Lancaster University.

Baretta, S. and Markoff, J. 2006 'Civilization and Barbarism' in Coronil, F. and Skurski, J. (eds.) States of Violence. Detroit, MI: University of Michigan Press.

Barry, A. (2006) 'Technological zones', European Journal of Social Theory, 9 (2), pp. 239-253.

Berne Declaration. (2013) Swiss Traders Opaque Deals in Nigeria. Zurich.

Boyd, W., Prudham, W.S., and Schurman, R.A. (2001) 'Industrial dynamics and the problem of nature', Society and Natural Resources, 14 (7), pp. 555-570.

Brecht, B. (1927) '700 Intellectuals Pray to an Oil Tanker', Revolutionary Democracy. Available at: https://revolutionarydemocracy.org/rdv9n2/poemsbb.htm.

Bridge, G. (2008) 'Global production networks and the extractive sector: Governing resource-based development', Journal of Economic Geography, 8 (3), pp. 389-419.

Bridge, G. (2015). 'The Hole World: Scales and Spaces of Extraction', Scenario Journal. Available at: https://scenariojournal.com/article/the-hole-world.

Chalfin, B. (2014) 'Public things, excremental politics, and the infrastructure of bare life in Ghana's city of Tema', American Ethnologist, 41 (106).

Christophers, B. (2019) 'The problem of rent', Critical Historical Studies, 6 (2), pp. 308-309.

Christophers, B. (2020). Rentier Capitalism. London: Verso.

Clark, M. (2014) 'Nigeria's oil thieves drive Shell To distraction as company plans pipeline sale', IB Times, 27 February, 2014.

Correa-Cabrera, G. (2017) Los Zetas Inc.: Criminal corporations, energy, and civil war in Mexico. Austin, TX: University of Texas Press.

Cowen, D. (2010) 'A geography of logistics: Market authority and the security of supply chains', Annals of the Association of American Geographers, 100 (3): pp. 600-620. 
Dalby, C. (2020) 'Three takeaways from the capture of 'El Marro' in Mexico'. Insight Crime. Available at: www.insightcrime.org/news/analysis/three-takeaways-el-marro-mexico.

De Boeck, F. (2012) Infrastructure: Commentary from Filip De Boeck. Curated Collections, Cultural Anthropology Online. Available at: https://journal.culanth.org/index.php/ca/ infrastructure-filip-de-boeck.

Duhaukt, A. (2017) Looting Fuel Pipelines in Mexico. Houston, TX: Baker Institute, Rice University.

Extractive Industries Transparency Initiative. (2015). The EITI, NOCs and the first trade. Oslo: EITI Secretariat.

Extractive Industries Transparency Initiative. (2018) Commodity trading transparency stocktake. Oslo: EITI Secretariat.

Ferguson, J. (2005) 'Seeing like an oil company', American Anthropologist, 107 (3), pp. 377-382.

Ferguson, J. (2006) Global shadows: African in the Neoliberal World Order. Durham, NC and London: Duke University Press.

Foreign Corrupt Practices Act Clearing House. (2019) Key Statistics. Stanford Law School. Available at: http://fcpa.stanford.edu/industry.html.

Garuba, D.S. (2010). 'Trans-border economic crimes, illegal oil bunkering and economic reforms in Nigeria', Policy brief series, 15.

Gelber, E. (2015). 'Rogue pipelines, oil and amnesty: The social life of infrastructure in the Niger Delta' (Doctoral dissertation, Columbia University).

Gereffi, G., Humphrey, J., and Sturgeon, T. (2005). 'The governance of global value chains', Review of International Political Economy, 12 (1), pp. 78-104.

Gibbon, P. (2004) 'Trading Houses during and since the Great Commodity Boom: Financialization, productivization or...?', DIIS Working Paper, Copenhagen, 2014(12).

Gillies, A., Gueniat, M., and Kummer, L. (2014) 'Big spenders: Swiss trading companies, African oil and the risk of opacity'. Zurich, Berne Declaration.

Gkanoutas-Leventis, A. (2017) Spikes and Shocks: The Financialization of the Oil Market from 1980 to the Present Day. London: Palgrave.

Gkanoutas-Leventis, A. and Nesvetailova, A. (2015) 'Financialisation, oil and the Great Recession', Energy Policy, 86, pp. 891-902.

Global Financial Integrity. (2013) Illicit Financial Flows and the Problem of Net Resource Transfers from Africa: 1980-2009. New York, NY: Global Financial Integrity.

Grandin, G. (2019) The End of the Myth: From the Frontier to the Border Wall in the Mind of America. New York, NY: Metropolitan Books.

Harvey, D. (2007) The Limits to Capital. London: Verso.

Hastings, J.V. and Phillips, S.G. (2015) 'Maritime piracy business networks and institutions in Africa', African Affairs, 114 (457), p. 573.

Hausmann, R. (1981) 'State landed property, oil rent, and accumulation in Venezuela: an analysis in terms of social relations'.

Henely, K. (2012) 'Review: The Forgotten Space', Slant Magazine. Available at: www.sla ntmagazine.com/film/the-forgotten-space.

Hertog, S. (2010) 'Defying the resource curse: Explaining successful state-owned enterprises in rentier states', World Politics, 62, pp. 261-301.

Hickey, S. and Izama, A. (2017) 'The politics of governing oil in Uganda: Going against the grain?’, African Affairs, 116 (463), pp. 163-185.

Ikanone, C.E.O. and Oyekan, P.O. (2014). 'Effect of boiling and frying on the total carbohydrate, vitamin $\mathrm{C}$ and mineral contents of Irish (Solanun tuberosum) and sweet (Ipomea batatas) potato tubers', Nigerian Food Journal, 32 (2), pp. 33-39.

Jacobsen, K.L. and Nordby, J.R. (2015) Maritime Security in the Gulf of Guinea. Copenhagen: Royal Danish Defence College Publishing House. 
Jensen, C. and Morita, S. (2015) 'Infrastructures as ontological experiments', Engaging Science, Technology, and Society, 1, pp. 81-87.

Jingzhong, Y., van der Ploeg, J.D., Schneider, S., and Shanin, T. (2020) 'The incursions of extractivism: Moving from dispersed places to global capitalism', The Journal of Peasant Studies, 47 (1), pp. 155-183,

Jones, N.P. and Sullivan, J.P. (2019) 'Huachicoleros: Criminal cartels, fuel theft, and violence in Mexico', Journal of Strategic Security, 12 (4), pp. 1-24.

Katsouris, C. and Sayne, A. (2013) Nigeria's Criminal Crude: International Options to Combat the Export of Stolen Oil. London: Chatham House.

Klinger, J.M. (2018) Rare Earth Frontiers: From Terrestrial Subsoils to Lunar Landscapes. Ithaca, NY: Cornell University Press.

KPMG. (2015) Clarity on commodities trading.

Labban, M. (2014) 'Deterritorializing extraction: Bioaccumulation and the planetary mine', Annals of the Association of American Geographers, 104 (3), pp. 560-576.

Lapavitsas, C. (2009) 'Financialised capitalism: Crisis and financial expropriation', Historical Materialism, 17 (2), pp. 114-148.

Larkin, B. (2013) 'The politics and poetics of infrastructure', Annual Review of Anthropology, 42, pp. 327-343.

Lefebvre, H. (2005) The Production of Space. Oxford: Blackwell.

Lombardi, M. (2003) Global Networks. New York, NY: Independent Curators.

Longchamp, O. and Perrot, N. (2017) Trading in Corruption: Evidence and Mitigation Measures for Corruption in the Trading of Oil and Minerals. U4 Anti-Corruption Centre.

Lopez-Lucia, E. (2015) Fragility, Conflict and Violence in the Gulf of Guinea (rapid literature review). Birmingham: GSDRC, University of Birmingham.

Lumpur, K. (2020) Unprecedented number of crew kidnappings in the Gulf of Guinea despite drop in overall global numbers. International Chamber of Commerce. Available at: https:// iccwbo.org/media-wall/news-speeches/unprecedented-number-of-crew-kidnappings-inthe-gulf-of-guinea-despite-drop-in-overall-global-numbers/\#: :text=The\%20number\% 20of $\% 20$ crew $\% 20$ kidnapped,last $\% 20$ quarter $\% 20$ of $\% 202019 \% 20$ alone.

Luning, S. (2018) 'Mining temporalities: Future perspectives', The Extractive Industries and Society, 5 (2), pp. 281-286.

Mark, M. (2012) 'Nigeria fuel subsidy scheme hit by corruption', The Guardian. Available at: www.theguardian.com/world/2012/apr/19/nigeria-fuel-subsidy-scheme-corruption.

Mason, A. (ed.) (Forthcoming) Arctic Abstractive Industry. Oxford and New York, NY: Berghan.

Mazzucato, M. (2018) The Value of everything: Making and taking in the global economy. London: Allen Lane.

McHugh, L. (2012). The Threat of Organised Crime to the Oil Industry. Future Directions International.

Mezzadra, S. and Neilson, B. (2017) 'On the multiple frontiers of extraction: Excavating contemporary capitalism', Cultural Studies, 31 (2-3), pp. 185-204.

Mezzadra, S. and Neilson, B. (2019) The Politics of Operations: Excavating Contemporary Capitalism. Durham, NC: Duke University Press.

Mihalyi, D., Adam, A., and Hwang, J. (2020) Resource-backed loans: pitfalls and potential. New York, NY: Natural Resource Governance Institute.

Mining Review Africa. (2019) 'The digital mine: How miners are turning a vision into reality', Mining Review Africa. Available at: www.miningreview.com/health-and-safety/ the-digital-mine-how-miners-are-turning-a-vision-into-reality.

Mommer, B. (1990) 'Oil Rent and rent Capitalism: The example of Venezuela', Fernand Braudel Center, 14, pp. 417-437. 
Moore, J.W. (2015) Capitalism in the Web of Life: Ecology and the Accumulation of Capital. London: Verso Books.

Murray, P. (2004) 'The Social and Material Transformation of Production by Capital: Formal and real subsumption in Capital' in Bellofiore, R. and N. Taylor (eds.) The Constitution of Capital: Essays on Volume 1 of Marx's Capital. Cham: Springer. pp. 243-272.

Nasir, J., (2020) 'Analysis: "N556bn spent on oil pipeline repairs since 2015"-Nigeria losing trillions to vandalism'. Petrobarometer. Available at: https://petrobarometer.theca ble.ng/2020/01/22/analysis-n556bn-spent-on-oil-pipeline-repairs-since-2015-nigeria -losing-trillions-to-vandalism/.

National Oil Spills Detection and Response Agency. (2020) Nigerian Oil Spill Monitor. Available at: https://oilspillmonitor.ng.

Ngada, T. and Bowers, K. (2018) 'Spatial and temporal analysis of crude oil theft in the Niger Delta', Security Journal, 31 (2), pp. 501-523.

Nigerian Bulletin. (2020) 'Nigeria lost N4.57tn revenue to crude oil theft in 4 years - maritime security review'. Available at: www.nigerianbulletin.com/threads/nigeria-lost-n4-57tn-re venue-to-crude-oil-theft-in-4-years-\%E2\%80\%93-maritime-security-review.413541.

Nigeria Extractive Industries Transparency Initiative. (2019) Nigeria's Oil and Gas Trading Pilot Report. Oslo/Abuja.

Nigeria National Petroleum Corporation. (2008-2018). Annual Statistical Reports. Annual Statistics Bulletin. Available at: www.nnpcgroup.com/Public-Relations/Oil-and-Gas-Sta tistics/Pages/Annual-Statistics-Bulletin.aspx.

Nigeria Natural Resources Charter. (2018) NNRC Assesses the impact of crude oil theft on Nigerians. Available at: www.nigerianrc.org/nnrc-assesses-the-impact-of-crude-oil-theft.

Nwajiaku-Dahou, K. (2012). "The political economy of oil and "rebellion" in Nigeria's Niger Delta', Review of African Political Economy, 39 (132), pp. 295-313.

Obama, B. (2020) A Promised Land. New York, NY: Crown Books.

Obi, C. and Rustad, S.A. (Eds.) (2011). Oil and Insurgency in the Niger Delta: Managing the Complex Politics of Petro-violence. London: Zed Books.

Ogunde, A. (2012) 'Nigeria loses over $\$ 500$ million monthly due to crude bunkering Shell'. Business News. Available at: http://businessnews.com.ng/2012/02/07/nigeria-lose s-over-500-million-monthly-due-to-crude-bunkering-shell.

Oil and Gas IQ. (2019) 'What does digital transformation in oil and gas look like?', Oil \& Gas IQ. Available at: www.oilandgasiq.com/oil-gas/news/what-is-digital-transformation.

Olawuyi, D. and Tubodenyefa, Z. (2018) Review of the Environmental Guidelines and Standards for the Petroleum Industry of Nigeria. Ado Ekiti: OGEES Institute, Afe Babalola University.

Omeje, K.C. (2006) High Stakes and Stakeholders: Oil Conflict and Security in Nigeria. London: Ashgate Publishing.

Organisation for Economic Co-operation and Development. (2014) OECD foreign bribery report: an analysis of the crime of bribery of foreign public officials. Paris: OECD Publishing.

Organisation for Economic Co-operation and Development. (2015) Material resources, productivity and the environment. Paris: OECD Publishing.

Organisation for Economic Co-operation and Development. (2016) Corruption in the extractive value chain: Typology of risks, mitigation measures and incentives. Paris: OECD Publishing, pp. 11-12.

Organisation for Economic Co-operation and Development. (2016) Corruption in the Extractive Value Chain: Typology of Risks, Mitigation Measures and Incentives. Paris: OECD Publishing.

Organisation for Economic Co-operation and Development. (2018) Global Material Resources Outlook to 2060. Paris. 
Østensen, Å.G. and Stridsman, M. (2017) 'Shadow Value Chains: Tracing the link between corruption, illicit activity and lootable natural resources from West Africa', U4 Issue.

Pérouse de Montclos, M.A. (2012) 'Maritime piracy in Nigeria: Old wine in new bottles?', Studies in Conflict \& Terrorism, 35(7-8), pp. 531-541.

Piketty, T. (2014) Capital in the Twenty-first Century. Cambridge, MA: Belknap Press of Harvard University Press.

Pirrong, C. (2014) The Economics of Commodity Trading Firms. Zurich: Trafigura.

Porter, D. and Watts, M. (2017) 'Righting the resource curse: Institutional politics and state capabilities in Edo State, Nigeria', The Journal of Development Studies, 53 (2), pp. 249-263.

Public Eye. (2017) Gunvor in Congo: Oil, Cash and Misappropriation of a Swiss Trader in Brazzaville. Zurich.

Ralby, I. and Soud, D. (2018) 'Oil on the water: Illicit hydrocarbons activity in the maritime domain', Atlantic Council.

Reinhart, L.B. (2014) 'The aftermath of Mexico's fuel-theft epidemic: Examining the Texas black market and the conspiracy to trade in stolen condensate', St. Mary's Law Journal, 45 (49), pp. 749-786.

Rexer, J. (2019) Black Market Crude. Philadelphia, PA: Kleinman Center for Energy Policy, University of Pennsylvania.

Ron, J. (2005) Frontiers and Ghettoes. Berkeley, CA: University of California Press.

Roy, P. (2017) Anti-Corruption in Nigeria: A political settlements analysis.

Sayne, A., Gillies, A., and Katsouris, C. (2015) Inside NNPC Oil Sales: A Case for Reform in Nigeria. New York, NY: Natural Resources Governance Institute.

Sayne, A., Gillies, S., and Watkins, A. (2017) Twelve Red Flags: Corruption Risks in the Award of Extraction Licenses and Contracts. New York, NY: Natural Resource Governance Institute.

Schmitt, C. (2003). The Nomos of the Earth in the International Law of the Jus Publicum Europaeum (trans. G.L. Ulmen). New York, NY: Telos.

Schouten, P., Stepputat, F., and Bachmann, J. (2019) 'States of circulation: Logistics off the beaten path', Environment and Planning D: Society and Space, 37 (5), p.780.

Signé, L., Sow, M., and Madden, P. (2020) Illicit Financial Flows in Africa. Washington, DC: The Brookings Institution.

Smith, M. (2020) 'Losses mount at idle Nigerian refineries', Petroleum Economist. Available at: www.petroleum-economist.com/articles/midstream-downstream/refining-marketing/ 2020/losses-mount-at-idle-nigerian-refineries.

Stakeholder Democracy Network. (2013) Communities not criminals: Illegal oil refining in the Niger delta. Port Harcourt: Stakeholder Democracy Network Publications.

Stakeholder Democracy Network. (2014) Communities not Criminals: Illegal Oil Refining in the Niger Delta. London and Port Harcourt: International Secretariat Development House.

Stakeholder Democracy Network. (2017) Communities Not Criminals: Illegal Oil Refining in the Niger Delta. Port Harcourt: Stakeholder Democracy Network.

Stakeholder Democracy Network. (2018) More Money, More Problems: Economic Dynamics of The Artisanal Oil Industry in The Niger Delta Over Five Years. Port Harcourt: Stakeholder Democracy Network.

Stakeholder Democracy Network. (2019) Pipeline Surveillance Contracts in the Niger Delta. Port Harcourt: Stakeholder Democracy Network.

Standing, G. (2016) The Corruption of Capitalism: Why Rentiers Thrive and Work Does Not Pay. London: Biteback.

Sullivan, J. (2012) From Drug Wars to Criminal Insurgency: Mexican Cartels, Criminal Enclaves and Criminal Insurgency in Mexico and Central America. Paris: Fondation Maison des Sciences de l'Homme. 
Swiss Federal Council. (2020) Supervision of commodity trading activities from the point of view of money laundering.

Szeman, I. (2017) 'On the politics of extraction', Cultural Studies, 31(2-3), pp. 440-447.

The Economist. (2019) 'The Gulf of Guinea is now the world's worst piracy hotspot', June 20, 2019. Available at: www.economist.com/international/2019/06/29/the-gulf-of-gui nea-is-now-the-worlds-worst-piracy-hotspot.

Tichý, L. (2019) 'The Islamic State oil and gas strategy in North Africa', Energy Strategy Reviews, 24, pp. 254-260.

Tsing, A. (2009). 'Supply chains and the human condition', Rethinking Marxism, 21 (2), pp. $148-176$.

United Nations Development Programme. (2006) Niger Delta Human Development Report. Abuja.

United Nations Economic Commission for Africa. (2018) Base Erosion and Profit Shifting in Africa: Reforms to Facilitate Improved Taxation of Multinational Enterprises. Addis Ababa: Economic Commission for Africa.

United Nations Environment Programme. (2019) Global Resources Outlook 2019. Nairobi.

United Nations Office on Drugs and Crime. (2009) Transnational Trafficking and the Rule of Law in West Africa. Vienna.

Van Drunen, S., Hartlief, I., Bassey, C., and Henshaw, K. (2020) Big Business, Low Profile: Shedding Light on Oil Trader Vitol's Operations in Nigeria. Amsterdam: SOMO.

Vienneast. (2016) An Investigation into Oil Smuggling and Revenue Generation by Islamic State. London: Vienneast.

Watts, M. (2007). 'Petro-insurgency or criminal syndicate? Conflict \& violence in the Niger Delta', Review of African Political Economy, 34 (114), pp. 637-660.

Watts, M. (2015) 'Spaces of Insurgency: power, place and spectacle in Nigeria' in Merrill, H. and Hoffman, L. (eds.) Geographies of Power: Re-cognizing the Present Moment of Danger. Athens, GA: University of Georgia Press, pp. 191-227.

Watts, M. (2018) 'Authority, precarity and conflict at the edge of the state' in Engels, B. and Dietz, K. (eds.) Climate Change in Africa: Social and Political Impacts, Conflicts and Strategies. Berlin: Peter Lang, pp. 167-206.

Weizman, E. (2007) Hollow Land: Israel's Architecture of Occupation. London: Verso Books.

Whanda, S., Adekola, O., Adamu, B., Yahaya, S., and Pandey, P.C. (2017) 'Geo-spatial analysis of oil spill distribution and susceptibility in the Niger delta region of Nigeria', Journal of Geographic Information Systems, 8, pp. 438-456.

Wiegink, N. (2018) Imagining booms and busts: Conflicting temporalities and the extraction "Development" nexus in Mozambique', The Extractive Industries and Society, 5 (2), pp. 245-252.

Yates, D.A. (1996) The Rentier State in Africa: Oil Rent Dependency and Neocolonialism in the Republic of Gabon. Trenton, NJ: Africa World Press.

Ye, J., van der Ploeg, J.D., Schneider, S., and Shanin, T. (2020). 'The incursions of extractivism: moving from dispersed places to global capitalism', The Journal of Peasant Studies, 47 (1), pp. 155-183.

Yusoff, K. (2017) 'Geosocial strata', Theory, Culture \& Society, 34(2-3), pp. 105-127. 